\title{
Мезозойский внутриконтинентальный орогенез в тектонической истории Колывань-Томской складчатой зоны, синтез геологических данных и результатов трекового анализа апатита
}

Жимулев Ф. И., Ветров Е. В., Новиков И. С., Ван Ранст Г. -., Начтергаеле С. -., Докашенко С. А., Де Граве Й. -.

\begin{abstract}
Аннотация
Колывань-Томская складчатая зона (КТСЗ) - расположенный в северо-западной части ЦентральноАзиатского складчатого пояса, коллизионный ороген, сформированный в поздней перми.

Позднепалеозойская КТСЗ в течение мезозоя испытала два импульса внутриконтинентального орогенеза. Первый из них произошел в позднем триасе - начале юры и сопровождался заложением южнее КТСЗ узких глубоких полуграбенов, выполненных грубообломочной континентальной ранне-среднеюрской молассой. Второй импульс орогенеза имеет позднеюрско-раннемеловой возраст. Он выразился в реактивации Томского надвига, по которому породы КТСЗ были надвинуты на ранне-среднеюрские осадочные бассейны. Мезозойский орогенез привел к эрозионному вскрытию гранитоидов барлакского комплекса, сформированных на внутриплитном этапе, после завершения пермского коллизионного тектогенеза. Наиболее вероятной причиной позднетриасово-раннеюрского орогенного события является закрытие океана Палеотетиса. Позднеюрско-раннемеловой орогенез связывается с закрытием Монголо-Охотского океана. Трековые возрасты апатита из гранитоидов приобского комплекса КТСЗ лежат в интервале 120100 млн лет, что соответствует аптскому и альбскому векам раннего мела. Выведение на земную поверхность горных пород с раннемеловыми трековыми возрастами связывается с эрозионным разрушением раннемелового орогена и образованием позднемеловой-палеогеновой поверхности выравнивания. Структурный план, каждой из рассмотренных реактиваций, не совпадая в деталях, наследует общие черты первичной, позднепалеозойской структуры Колывань-Томской складчатой зоны.
\end{abstract}

\section{Ключевые слова:}

Внутриконтинентальный орогенез, мезозой, Западная Сибирь, трековая термохронология, поверхности выравнивания, молассы, граниты 
Мезозойский внутриконтинентальный орогенез в тектонической истории Колывань-Томской складчатой зоны (Южная Сибирь), синтез геологических данных и результатов трекового анализа апатита

Mesozoic intracontinental orogeny in the tectonic history of the Kolyvan-Tomsk folded zone (South Siberia), a synthesis of geological data and apatite fission track analysis

Жимулев1 Ф. И., Ветров1 Е. В., Новиков1 И. С., Ван Ранст2 Г., Начтергаеле2 С., Докашенко1 С. А., Де Граве2 Й.

Zhimulev1 F. I., Vetrov1 E. V., Novikov1 I. S., Van Ranst2 G., Nachtergaele2 S., Dokashenko1 S. A., De Grave2 J.

1 Институт геологии и минералогии им. В. С. Соболева СО РАН, Новосибирск, Россия

\section{2 Гентский университет, Гент, Бельгия}

1Sobolev Institute of Geology and Mineralogy Siberian Branch Russian Academy of Sciences, Novosibirsk 630090 Koptuga ave. 3, Russia

2Department of Geology, Ghent University, Krijgslaan 281.S8, WE13, 9000 Gent, Belgium

\section{Аннотация}

Колывань-Томская складчатая зона (КТСЗ) - расположенный в северо-западной части Центрально-Азиатского складчатого пояса, коллизионный ороген, сформированный в поздней перми. Позднепалеозойская КТСЗ в течение мезозоя испытала два импульса внутриконтинентального орогенеза. Первый из них произошел в позднем триасе - начале юры и сопровождался заложением южнее КТСЗ узких глубоких полуграбенов, выполненных грубообломочной континентальной ранне-среднеюрской молассой. Второй импульс орогенеза имеет позднеюрско-раннемеловой возраст. Он выразился в реактивации Томского надвига, по которому породы КТСЗ были надвинуты на ранне-среднеюрские осадочные бассейны. Мезозойский орогенез привел к эрозионному вскрытию гранитоидов барлакского комплекса, сформированных на внутриплитном этапе, после завершения пермского коллизионного тектогенеза. Наиболее вероятной причиной позднетриасово-раннеюрского орогенного события является закрытие океана Палеотетиса. Позднеюрско-раннемеловой орогенез связывается с закрытием Монголо-Охотского океана. Трековые возрасты апатита из гранитоидов приобского комплекса КТСЗ лежат в интервале 120-100 млн лет, что соответствует аптскому и альбскому векам раннего мела. Выведение на земную поверхность горных пород с раннемеловыми трековыми возрастами связывается с эрозионным разрушением раннемелового орогена и образованием позднемеловойпалеогеновой поверхности выравнивания. Структурный план, каждой из 
рассмотренных реактиваций, не совпадая в деталях, наследует общие черты первичной, позднепалеозойской структуры Колывань-Томской складчатой зоны.

\section{Abstract}

The Kolyvan-Tomsk fold zone (KTFZ) is a collisional orogen, located at the northernwestern part of the Central Asian orogenic belt, and formed in the Late Permian. The Late Paleozoic KTFZ subsequently experienced two pulses of intracontinental orogenesis during the Mesozoic. The first of them occurred in the Late Triassic - Early Jurassic and was accompanied by the formation of narrow, deep semi-grabens filled up by coarse clastic continental Early-Middle-Jurassic molasses. The second orogenic event can be dated as late Jurassic-Early Cretaceous. This second event lead to the reactivation of the Tomsk thrust, whereby the KTFZ Paleozoic rocks are overthrust on to the EarlyMiddle Jurassic sedimentary basins. The Mesozoic orogenic events led to the erosion of the granitoid rocks of the Barlak complex, formed in the intraplate context, following the completion of the Permian collisional orogeny. The most likely cause of the Late Triassic-Early Jurassic orogenic event is the closure of the Paleothetys ocean. Late Jurassic-Early Cretaceous orogenesis is associated with the closure of the MongolOkhotsk ocean. Apatite fission-track ages from the granitoids of the Priob complex from the KTFZ are in the range of 120-100 Ma, which corresponds to the Aptian and Albanian (Early Cretaceous). The exhumation of these rocks to the earth's surface is associated with erosion and peneplanation of the Early Cretaceous orogeny, producing a widespread Late Cretaceous-Paleogene planation surface. The aforementioned reactivation episodes in general follow the structural pattern inherited from the ancestral Late Permian collisional orogeny.

\section{Ключевые слова:}

Внутриконтинентальный орогенез, мезозой, Западная Сибирь, трековая термохронология, поверхности выравнивания, молассы, граниты, ЦентральноАзиатский складчатый пояс

Key words:

Intracontinental orogeny, Mesozoic, Western Siberia, track thermochronology, erosion surfaces, molasses, granites, Central Asian orogenic belt

\section{1. Введение}

Колывань-Томская складчатая зона (КТСЗ) является северной, обнаженной частью Обь-Зайсанской складчатой системы Центрально-Азиатского складчатого пояса (ЦАСП) [Матвеевская, 1969], а в ряде работ рассматривается в составе АлтаеСаянской складчатой области (АССО), образуя северо-западную окраину последней (Сотников и др., 1999). КТСЗ простирается в северо-восточном направлении на расстояние около 450 км при ширине 60-100 км (Рис. 1) и представляет собой позднепалеозойский (герцинский) ороген со складчатопокровным строением. С юга, запада и севера структуры КТСЗ перекрыты 
мезозойско-кайнозойским чехлом Западно-Сибирской плиты, а на юго-востоке надвинуты на раннепалеозойские складчатые комплексы Салаира и позднепалеозойский чехол Кузнецкого прогиба. Большинство работ, посвященных геологическому строению КТСЗ и истории геологического развития региона, ограничивается палеозойским этапом [Матвеевская 1969; Врублевский и др., 1987; Кунгурцев и др., 1998; Сотников и др., 1999; Росляков и др., 2001; Zhimulev et al., 2020]. История геологического развития на постскладчатом этапе, охватывающем мезозой и кайнозой, рассматривалась тезисно, в рамках представлений о субплатформенном этапе развития, характеризующемся только малоамплитудными блоковыми движениями.

В то же время, известно, что в мезозойское время многие палеозойские складчатые зоны ЦАСП были реактивированы, и на их месте возникли внутриконтинентальные орогены. Этот факт был установлен, исходя из геологических данных [Обручев, 1948; Боголепов, 1967; Башарина и др., 1974]. Позднее, в результате развития методов низкотемпературной термохронологии, данные о неоднократности проявления этапов внутриконтинентального орогенеза в геологической истории были подтверждены, а геология получила новый инструмент выявления и изучения этих событий [Fleischer et al., 1975; Wagner, 1968; Wagner, Reimer 1972; Wagner, Van den Haute, 1992]. Актуалистической основой для изучения процессов древнего внутриконтинентального орогенеза служит современный Центрально-Азиатский горный пояс, возникший в позднем кайнозое на территории палеозойских сооружений ЦАСП, таких, как Тянь-Шань, Джунгарский Алатау, Алтай и т.д. Установлено, что формирование этой крупнейшей неотектонической структуры связано с продолжающейся континентальной коллизией Евроазиатской и Индо-Австралийской литосферных плит [Molnar, Tapponnier, 1975; Hendrix et al., 1994; Delvaux et al., 2013; Dobretsov et al., 1996; Yin, Harrison, 2000; De Grave et al., 2007a], что открыло возможности к интерпретации древних орогенических этапов в рамках тектоники литосферных плит. В настоящее время тектонические перестройки ЦАСП на континентальном этапе развития, охватывающем мезозой и кайнозой, связываются с подобными коллизионными событиями на окраинах Евразии [De Grave et al., 2007a; Glorie, De Grave, 2016; Yang et al., 2017]. Пространственно-временная динамика формирования внутриконтинентальных орогенов мезозойского возраста в пределах ЦАСП, является актуальным вопросом тектоники и интенсивно изучается в последние годы [Jolivet, 2015; Jolivet et al., 2017; Glorie et al., 2019, Nachtergaele et al., 2018; De Pelsmaeker et al., 2018; Новиков и др., 2019; Михеева и др., 2017; Vetrov et al., 2020]. На юге Западной Сибири наиболее ярким свидетельством мезозойской тектонической активности, являются узкие и глубокие впадины, выполненные юрскими терригенными угленосными отложениями. Для КТСЗ в настоящее время опубликована только одна трековая датировка без реконструкции термальной истории [De Grave et al., 2007b].

Работы, рассматривающие кайнозойскую и, в особенности, мезозойскую историю КТСЗ и южной части Западной Сибири в целом [Адаменко, 1976; Башарина и др., 1974; Боголепов, 1967; Вдовин, 1976; Малолетко, 1972] в настоящее время 
нуждаются в уточнении и переосмыслении в связи с появлением новых теоретических концепций, методов и фактических данных.

Целью настоящего исследования является описание мезозойско-кайнозойской тектонической истории Колывань-Томской складчатой зоны в контексте современных представлений о причинах и механизмах внутриконтинентального орогенеза. В предлагаемой работе проведен обзор геологических свидетельств мезозойского внутриконтинентального орогенеза КTС3, а также приведены первые модели термальных историй, полученные по результатам трекового анализа апатита из позднепермских гранитоидов КТСЗ. В качестве геологических индикаторов различных тектонических режимов, рассмотрены синорогенные (согласно признакам, изложенным в работах [Башарина, 1975; Бувалкин, 1978]) осадочные бассейны, коры выветривания и геологические данные о времени выведения на поверхность гранитоидных интрузивов.

\section{2. Геологические свидетельства мезозойского внутриконтинентального орогенеза.}

Ведущим методом изучения процессов внутриконтинентального орогенеза является изучение синорогенных межгорных осадочных бассейнов, осадочная летопись которых отражает этапность развития смежных тектонических структур. В зоне сочленения КТСЗ и Салаира на позднепалеозойскую складчато-покровную структуру наложена система юрских осадочных бассейнов, представляющих собой глубокие и небольшие по площади тектонические депрессии. Для анализа структурного положения юрских прогибов ниже приведена краткая характеристика позднепалеозойской структуры доюрского фундамента. КТСЗ представляет собой пакет тектонических пластин, сложенных породами среднего-девона - раннего карбона и шарьированных в юго-восточном направлении на структуры Салаира и Кузнецкого прогиба. Фронтальный надвиг КТСЗ на разных участках зоны носит разные названия, для простоты, далее он везде называется Томским. Перед Томским надвигом расположен форландовый Горлово-Зарубинский прогиб, протягивающийся вдоль фронта надвигов КТСЗ примерно на 450 км при ширине 13-18 км. В структурном отношении, Горловский прогиб представляет собой резко асимметричную грабен-синклиналь, юго-восточной вергентности. Для северозападного крыла, обращенного к аллохтону КТС3, характерно крутое залегание (70-80), иногда переходящее в вертикальное или запрокинутое. Юго-восточное крыло Горловского прогиба более пологое. Оно также осложнено надвиговой зоной, по которой осадочные комплексы Горловского прогиба надвинуты на каледониды Салаира, перекрытые прерывистым и деформированным осадочным чехлом девонско-нижнекарбонового возраста. При дальнейшем описании, обе надвиговых зоны рассматриваются нами как южная и северная ветви единой зоны Томского надвига. Горловский прогиб представляет собой не автохтон, а шарьированный параавтохтон, поэтому нередко включается в состав КТСЗ в качестве одной из тектонических пластин. Горловский прогиб выполнен преимущественно, терригенными отложениями, верхнего девона - перми. Самые молодые отложения прогиба образованы кольчугинской серией средней-поздней перми. Горлово-Зарубинский прогиб является форландовым бассейном, 
возникшим при надвигании структур КТСЗ на окраину континента [Сотников и др., 19994; Жимулев и др., 2017], сложенную каледонидами Салаира.

Юрские грабен-синклинальные бассейны наложены на структуры ГорловоЗарубинского предгорного прогиба, образуя цепочку параллельную Томскому надвигу. Установлено тектоническое перекрытие юрских отложений палеозойскими породами КТСЗ. Юрские отложения почти повсеместно перекрыты чехлом кайнозойских отложений. Естественные обнажения юрских пород встречаются только на южном краю Доронинской впадины. Геологическое строение юрских бассейнов приводится на основании отчетов и объяснительных записок [Ахмадщин и др., 2008; Бабин и др, 2007, 2015; Беляев, Нечаев, 2015; Звонарев, 1965; Котельников и др., 2008]. В направлении с северо-востока на югозапад наблюдаются следующие юрские впадины: Улановская, Доронинская, Карагужевская и Бобровская (Рис. 1).

\section{1. Улановская впадина.}

Впадина расположена перед фронтом Томского надвига на северо-востоке КТСЗ, где простирание зоны изменяется с северо-восточного до субмеридионального [Ахмадщин и др., 2008]. Она имеет северо-западное простирание, ширина ее составляет до 20 км, длина превышает 30 км. Поперечный разрез впадины асимметричен. Наиболее глубокая ее часть находится на севере, вблизи ограничивающего впадину разлома широтного простирания. Мощность юрских отложений, выполняющих впадину, точно не установлена и по геофизическим данным оценивается в 460-480 м. В южном направлении глубина впадины уменьшается постепенно. С запада впадина ограничена Томским надвигом, по которому складчатые девон-карбоновые комплексы надвинуты на юрские отложения.

Улановская впадина выполнена субгоризонтально залегающей континентальной угленосной юрской молассой (Рис. 2). В разрезе выделяются три свиты макаровская, иланская и итатская. Макаровская свита мощностью 160 м залегает с размывом на палеозойских образованиях. Она представлена алевролитами зеленовато-серыми, песчаниками зеленовато-серыми, среднезернистыми, бурыми углями и углистыми аргиллитами. Возраст свиты раннеюрский. Иланская свита согласно перекрывает макаровскую свиту. От нижележащих отложений отличается преобладанием грубообломочных пород и отсутствием углей. Свита сложена конгломератами с преобладанием гальки и отдельных валунов песчаников и алевролитов, песчаниками серыми, среднезернистыми, алевролитами и аргиллитами. Общая мощность свиты 90 м. Выделенный палинокомплекс соответствует тоарскому ярусу нижней юры. Вышележащая итатская свита представлена переслаивающимися аргиллитами и алевролитами с прослоями песчаников, конгломератов и бурых углей. Обломочный материал полимиктового состава, слабо окатан и не сортирован. Аргиллиты слабо сцементированы и часто представляют собой плотные глины. Возраст свиты соответствует средней юре на основании флоры и видового состава спор и пыльцы [Григорьев, Сазонов, 1964]. 
Всеми исследователями отмечается изменчивость состава и мощности юрских отложений в Улановской впадине. Обломочный материал конгломератов слабо окатан, его гранулометрический и вещественный состав меняется в зависимости от местоположения разреза. Грубообломочные типы пород преобладают у бортов впадины. Например, в работе [Геология СССР..., 1967] указано, что макаровская свита сложена преимущественно конгломератами, а мощность ее составляет около 60 м. Вероятно, эти данные относятся к краевой части впадины. В центральной ее части возрастает роль алевролитов, аргиллитов и бурых углей. Накопление раннесреднеюрских отложений происходило одновременно с формированием впадины. На северо-восточном борту впадины юрские породы по Томскому надвигу тектонически перекрыты девон-карбоновыми породами КТСЗ. Отложения симоновской свиты туронского возраста перекрывают Томский надвиг в районе Улановской впадины. Они представлены нелитифицированными глинами и кварцевыми песками, содержат бокситы, имеют небольшую мощность и залегают субгоризонтально.

\section{2. Доронинская впадина}

Доронинская впадина наиболее крупная из юрских впадин района, простирается с запада на восток примерно на 70 км, при максимальной ширине в 25 км и имеет площадь около 1000 км². Она представляет собой типичный полуграбен, осадочное выполнение которого образует осложненную разломом брахисинклинальную структуру (Рис. 3). Углы погружения слоистости на южном, пологом крыле изменяются в диапазоне от 0 до 20², северное крыло и центриклинальные замыкания срезаны надвигом, ограничивающим с юга Горловский прогиб и являющимся южной ветвью Томского надвига. Таким образом, Доронинская впадина может рассматриваться как полурамповая структура, согласно определению [Willis, 1928]. В плане впадина имеет форму линзы, выпуклой в южном направлении. Максимальная мощность юрских отложений, наблюдается вблизи северного, ограниченного надвигом борта впадины и составляет около 1500 м [Беляев, Нечаев, 2015; Бабин, 2015], а по некоторым оценкам достигает 1880 м [Звонарев, 1965; Вдовин, 1976].

Доронинская впадина выполнена толщей континентальных угленосных отложений, несогласно залегающих на сложном по составу комплексе пород палеозойского фундамента. Юрский разрез впадины соответствует тарбаганской серии ранне- среднеюрского возраста, которая подразделяется на распадскую, абашевскую, осиновскую и терсюкскую свиты (Рис. 2).

Распадская свита мощностью от 230 до 690 м сложена преимущественно песчаниками, с подчиненным количеством алевролитов, аргиллитов и отдельными прослоями угля. Нижняя часть разреза свиты в естественных обнажениях на южном борту впадины сложена галечными и валунно-галечными конгломератами (Рис. 4a), гравелитами и грубозернистыми песчаниками, отдельные валуны достигают 50 см в диаметре. Обломочный материал, в основном, плохо отсортирован, слабо окатан. В составе гальке преобладают измененные эффузивы и туфы основного и кислого состава, встречаются известняки и граниты. Состав 
обломочного материала указывает на ближний перенос с северного Салаира. Также в составе конгломератов Доронинской впадины описаны обломки бокситов [Фомичев, Алексеева, 1961], вынесенных при размыве коры выветривания позднетриасового пенеплена Салаира. На основании изучения палиноспектров определен геттанг-синемюрский возраст распадской свиты. Вышележащая абашевская свита по составу и структурно-текстурным особенностям пород близка распадской свите. Мощность абашевской свиты изменяется от 150 до 260 м. Абашевская свита согласно перекрыта осиновской свитой, сложенной серыми, зеленовато-серыми алевролитами с прослоями песчаников, аргиллитов и углей. Мощность отложений осиновской свиты колеблется от 330 до 360 м, а возраст определяется как конец плинсбаха - начало тоара. Разрез вышележащей терсюкской свиты имеет сложное ритмическое строение, меняющееся по вертикали и латерали на коротком расстоянии. Свита сложена преимущественно аргиллитами, алевролитами и мелкозернистыми песчаниками, угли составляют около 5 \% объема свиты, конгломераты и гравелиты образуют единичные прослои. Мощность свиты варьирует от 90 до 270 м. Возраст свиты определяется как тоарааленский.

Для всех свит характерны резкие изменения мощности и размера зернистости обломочного материала в латеральном направлении. Доля грубообломочных пачек и гранулометрическая размерность обломочного материала увеличиваются в южном и западном направлениях.

По юрским отложениям развита кора выветривания позднемеловогораннепалеогенового облика. Юрские отложения впадины перекрыты тонким, субгоризонтально залегающим чехлом кайнозойских осадков, включающих олигоцен-неогеновые глины и плейстоценовые лессовидные суглинки.

\section{3. Карагужевская и Бобровская впадины}

Карагужевская впадина расположена на складчатом палеозойском фундаменте, включающем позднепалеозойский Горловский прогиб и, частично, каледониды Западного Салаира и представляет собой широтно ориентированную мульду, 25 км в длину и 15 км в ширину. Впадина выполнена ранне-среднеюрскими отложениями тарбаганской серии мощностью 300-400 м. [Котельников и др., 2015]. Углы падения крыльев очень пологие, но на отдельных участках отмечались крутые падения слоёв, вероятно, представляющие собой флексуры над разрывными нарушениями. Согласно [Бабин и др., 2015] юрские отложения впадины перекрывают Томско-Каменский надвиг, а по Карасевскому разлому на них надвинуты карбоновые породы Горловского прогиба. Геологическое строение впадины охарактеризовано только несколькими скважинами [Котельников и др., 2015]. Принимая во внимание большую мощность отложений по отношению к размерам впадины и резкие изменения углов падения слоистости, Карагужевская впадина может иметь преимущественно тектонические контакты и представлять собой грабен-синклиналь. 
Бобровская впадина расположена на крайнем юго-западе КТСЗ. Она представляет собой субширотно ориентированную брахисинклиналь (20 км в длину и 5-10 км в ширину), выполненную отложениями ранне-среднеюрской тарбаганской серии, мощностью несколько сотен метров.

Впадины сходного строения, выполненные однотипным комплексом юрских терригенных пород и перекрытые осадочным чехлом Западно-Сибирской плиты, широко распространены на юге Западной Сибири. Нами были охарактеризованы только впадины, структурно приуроченные к КТСЗ. Подводя итог их рассмотрению, можно отметить следующие общие черты строения. Юрские отложения образуют обособленный структурный этаж, отделенный от палеозойского фундамента и мел-палеогенового чехла структурными несогласиями, длительными стратиграфическими перерывами и эпохами формирования кор выветривания. Юрские отложения, в особенности нижняя часть их разреза, представлены грубообломочными отложениями (вплоть до галечновалунных конгломератов), которые могли формироваться в условиях расчлененного рельефа. Резкая латеральная изменчивость мощности и гранулометрического состава юрских отложений, а также приуроченность юрских бассейнов к разрывным нарушениям, свидетельствуют о синтектоническом характере осадконакопления. Юрские впадины имеют два типа тектонических ограничений. Структуры первого типа - преимущественно субширотные разломы, конседиментационные по отношению к ранне-среднеюрским отложениям. Кинематический тип этих разломов не вполне определен. Второй тип тектонических границ- представлен Томским надвигом, наиболее поздняя стадия тектонической активности которого, была постседиментационной по отношению к ранне-среднеюрским бассейнам. Разломы первого типа утыкаются в Томский надвиг [Ахмадщин и др., 2008]. Юрские впадины наложены преимущественно на структуры Горловского прогиба перед фронтом КТСЗ.

\section{4. Эрозионное вскрытие гранитоидных интрузивов}

В пределах КТСЗ распространены два гранитоидных комплекса - позднепермскораннетриасовый приобский монцодиорит-граносиенит-гранитовый и раннесреднетриасовый барлакский гранит- лейкогранитовый [Сотников и др., 2000; Бабин и др., 2015]. Учитывая новые данные уран-свинцового датирования [Бабин и др., 2015] возраст приобского комплекса может быть принят позднепермским. По гранитоидам обоих комплексов широко развиты мел-палеогеновые красноцветные коры выветривания [Коры выветривания..., 1979]. По геофизическим данным количество и размеры гранитоидных массивов возрастают с глубиной и некоторые соседние изолированные массивы, как приобского, так и барлакского комплексов представляют собой выступы кровли единых батолитов [Вериго, 1969; Васютинская, Михайловский, 1963; Бабин и др., 2015]. Становление многофазных батолитов приобского комплекса связывается с коллизионным этапом развития складчатой области, и эрозионное вскрытие их могло быть связано с разрушением первичного коллизионного орогена [Сотников и др, 1999, 2000]. Интрузивы 
барлакского лейкогранитового комплекса формировались во внутриплитных условиях в период относительной тектонической стабильности [Вериго 1969; Сотников и др., 2000]. На это указывает резкая дискордантность контактов, округлая форма массивов в плане, однородность состава и отсутствие гибридных разностей. Образование коллизионного орогена КТСЗ завершилось на рубеже перми и триаса, о чем свидетельствует пермский возраст наиболее молодых континентальных моласс (кольчугинская серия) в Горловском передовом прогибе. Тектоническая стабильность региона в триасовом периоде общепризнана [Матвеевская 1969; Вдовин, 1976; Сотников и др., 1999].

В борту Колыванского каменного карьера (55²1'19.73"С, 8246'4.82"В), наблюдается следующий разрез (Рис. 4б). На неизмененных лейкогранитах барлакского комплекса сформирована кора выветривания, представленная суглинками малиново-красного цвета. Кора выветривания перекрыта палевобурыми лессовидными суглинками краснодубровской свиты четвертичного возраста. Согласно существующим представлениям о палеоклиматах и облике кор выветривания, малиново-красные суглинки, часто содержащие бокситы, формировались в регионе в позднем мелу и палеоцене, когда климат региона был тропическим [Кулькова, Волкова, 1997]. Эоценовые и более молодые коры выветривания характеризуются меньшей зрелостью и бурой окраской [Волков, Казьмин, 2007]. Таким образом, эрозионное вскрытие гранитных массивов барлакского комплекса произошло в интервале времени с позднего триаса до палеоцена. Начиная с позднего мела регион находился в тектонически стабильном режиме, о чем свидетельствует сохранность кор выветривания на значительных территориях [Коры выветривания..., 1979; Бабин и др., 2015].

В районе с. Инское, в зоне разлома, отделяющего Горловский прогиб от Салаира, карьером вскрыт небольшой массив кварцевых диорит-порфиритов, подобных по составу гранитоидам приобского возраста [Котельников и др., 2015]. Данный массив может представлять собой апикальную часть массива гранитоидов приобского комплекса [Котельников и др., 2015], залегающего на глубине, в этом случае можно говорить о значительном различии эрозионного среза палеозойской структуры в КТСЗ и Горловском прогибе.

\section{3. Методика трекового датирования}

Трековый анализ основан на накоплении радиационных повреждений в минералах, содержащих уран (апатит, циркон, сфен). Трековый анализ апатита является методом геологического датирования, который основан на подсчете плотности треков осколков спонтанного деления ядер урана-238, накапливающихся в минерале в ходе геологической истории. Линейные зоны повреждения, называемые треками распада, получаются в результате прохождения высокоэнергетических фрагментов распада через кристаллическую решетку. После простой химической процедуры травления, треки распада могут наблюдаться под микроскопом в виде цилиндроподобных отверстий (Рис. 5). Треки производятся непрерывно со временем и, например, в апатите, начальная длина протравленного трека составляет в среднем $16 \pm 1$ мкм, а диаметр - 1-2 мкм. При воздействии 
высоких температур, радиационное повреждение, формирующее треки, постепенно отжигается (иначе говоря, залечивается) и исчезает, постепенно сбрасывая запись трековых часов до нуля. Температура - это главный физический фактор, действующий на процесс отжига трека, в то время, как другие факторы, включающие давление, деформацию, флюиды и выветривание имеют незначительный эффект на отжиг трека или не имеют совсем [Kohn et al., 2002]. Температурный интервал, выше которого треки залечиваются (температура закрытия системы для данного метода) является индивидуальной характеристикой для каждого минерала. В апатите температура отжига варьирует в диапазоне 100 $120^{\circ}$ С. Изучение треков, описание процессов отжига и применение термальных историй к геологическим процессам представлены в работах [Wagner, Van den haute, 1992; Gleadow, Brown, 2000] и др. С помощью данных трековой термохронологии возможна реконструкция термальной истории пород и, следовательно, событий охлаждения горных пород в обстановке верхней континентальной коры. Такие исследования, позволяют выявлять периоды тектонической стабилизации (пенепленизации) и активности (горообразования). Трековое датирование апатитов проведено в лаборатории минералогии и петрологии Гентского университета (MINPET, Ghent University) по стандартной методике с помощью метода внешнего детектора с использованием теплового нейтронного облучения [De Grave, Van den haute, 2002; Glorie et al., 2010; De Pelsmaeker et al., 2015; Nachtergaele et al., 2018; Van Ranst et al., 2020]. Треки спонтанного деления U-238 в апатите подвергались химическому травлению $5.5 \mathrm{M}$ раствором азотной кислоты в течение 20 секунд при температуре $21^{\circ} \mathrm{C}$. Индуцированные треки U-235 проанализированы в мусковитовом внешнем детекторе после облучения и травления 40\% раствором плавиковой кислоты в течение 40 минут при температуре $20^{\circ} \mathrm{C}$. Облучение капсулы с пробами, стандартами и дозиметрами проводилось на бельгийском реакторе 1 (BR1) в бельгийском ядерном исследовательском центре г. Мол (Belgian Nuclear Research Centre in Mol). В качестве стандартов были использованы апатиты из туфов Durango [McDowell et al., 2005] и Fish Canyon [Hurford, Hammerschmidt, 1985], в качестве дозиметра - оптимизированное стекло IRMM 540 [De Corte et al., 1998]. Подсчет треков произведен на сканирующем микроскопе Nikon. Калибровка трековых возрастов осуществлялась с использованием усредненного зета-фактора. В дополнение к определению трековых возрастов, получено распределение трековых длин, что позволило определить характер охлаждения пород и восстановить термальную историю образцов горных пород с помощью термотектонического моделирования. Моделирование термальных историй проведено при наличии необходимого количества измерений трековых длин (от 50 до 100) с использованием программного обеспечения QTQt [Gallagher, 2012].

\section{4. Результаты трекового датирования.}

Объектом для трекового датирования служил магматогенный акцессорный апатит гранитоидных интрузий. Гранитоидные породы обнажены в пределах КТСЗ весьма ограничено. Они вскрыты карьерами и обнажены в районе города Новосибирска, а также в нескольких пунктах в долине реки Оби (села Дубровино, Новобибеево). В работе представлены результаты трекового датирования апатитов четырех 
образцов, гранитоидов второй фазы приобского позднепермского комплекса: обр. C-1 монцограниты Новосибирского массива с U-Pb возрастом цирконов 256 млн лет, обр. 14-279 - граносиениты Новосибирского массива с U-Pb возрастом цирконов 258 млн лет, обр. 15-519 - монцограниты Обского массива с U-Pb возрастом цирконов 261 млн лет, 17-1346- гранодиорит-порфириты, в районе села Инского (Рис. 1, Табл. 1).

Результаты трекового датирования представлены в таблице 2, а термальные истории и гистограммы распределения трековых длин на рис. 6. Для образца С-1 получен раннемеловой трековый возраст апатита 118,1+12,9 млн лет. Средняя

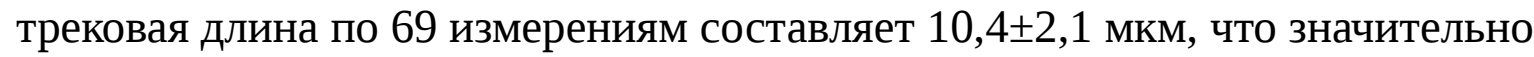
меньше средней длины новообразованных треков (16,3 мкм) и может свидетельствовать о длительном пребывании в зоне частичного отжига $\left(60-120^{\circ} \mathrm{C}\right)$. Гистограмма распределения трековых длин характеризуется широким основанием и слабо проявленной бимодальностью, что может быть вызвано, как минимум, двумя этапами быстрого охлаждения. В термальной истории образца С-1 отчетливо выделяются два контрастных этапа (мел-палеогеновый и неогеновый), отражающие различные тектонические режимы. Наличие юрского этапа быстрого охлаждения можно только предполагать по воздыманию T-t-тренда при условной экстраполяции первичной модели термальной истории. На протяжении всего мела в течение почти 80 млн лет образец C-1 был охлажден максимум на $40^{\circ} \mathrm{C}$, иначе говоря, скорость денудации на этом временном интервале не превышала 2 м/млн лет. Такие значения являются показателем тектонической стабильности тектонического блока, из которого был отобран образец С-1. Во время палеоцена и эоцена T-t-тренд термальной истории погружается в связи с нагреванием (от 60 до $70^{\circ} \mathrm{C}$ ), которое может быть вызвано погружением в результате накопления осадочной последовательности. По прямым расчетам (с учетом среднего геотермического градиента исследуемой территории $25-30^{\circ} \mathrm{C}$ на 1 км) можно предположить, что суммарная мощность отложений, накопившихся в палеоценеэоцене составляла 250-300 м. Возможно, именно этот эпизод погружения привел к возврату образца C-1 в зону частичного отжига, где трековая система апатита была частично перезагружена. Проседание прекратилось к олигоцену, во время которого термальная история характеризуется горизонтальным поведением тренда.

По образцу 14-279 получен трековый возраст апатита 99,9ะ12,6 млн лет, что соответствует границе раннего и позднего мела. Средняя трековая длина по 70

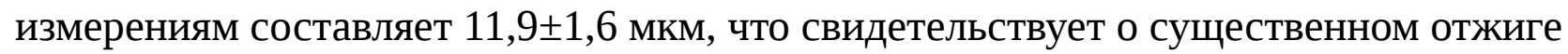
треков. Трековая история, смоделированная по данным анализа треков образца 14279, подобна термальной истории образца C-1 и может дополнить ее. В отличие от образца С-1, термальная история образца 14-279 проявила раннемеловой этап быстрого охлаждения в диапазоне 140-110 млн лет. Скорость охлаждения на этом этапе составила 65-70 м/млн лет.

Для образца 15-519 рассчитан раннемеловой трековый возраст 108,9ะ11,6 млн лет. Значение средней трековой длины получено по 50 измерениям и составляет 13,2士1,5 мкм. Высокое значение средней трековой длины и распределение длин треков спонтанного деления на гистограмме свидетельствует о хорошей 
сохранности треков в апатите из образца 15-519, который отобран из другого массива (неотектонического блока) нежели два предыдущих образца. Термальная история подчеркивает самостоятельность этого неотектонического блока - по образцу 15-519 не выделяются обособленные термотектонические режимы, образец на протяжении 120 млн лет испытывал длительное монотонное охлаждение со скоростью 0,40 С/млн лет, что соответствует скорости денудации 12-15 м/млн лет.

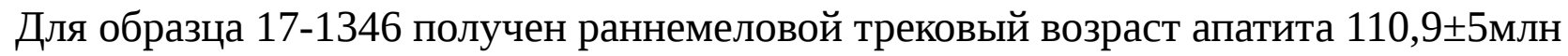

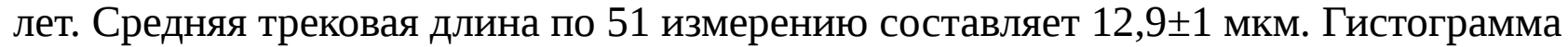
распределения трековых длин свидетельствует об отжиге треков в зоне частичного отжига. В термальной истории образца 17-1346 выделяются меловой и неогеновый этапы быстрого охлаждения, разделенные этапом нагревания на протяжении всего палеогена. Образец на протяжении мела охлаждался со скоростью 20 С/млн лет, что соответствует скорости денудации около 60-75 м/млн лет. Во время палеогена T-t-тренд термальной истории погружается в связи с нагреванием (от 45 до 65드), которое может быть вызвано погружением. В начале неогена образец 17-1346 испытал заключительную фазу быстрого охлаждения и был выведен на поверхность.

\section{5 Обсуждение результатов}

Последовательность тектонических событий в регионе представляется в следующем виде. Коллизионные деформации, включающие складчатость и покровообразование в КТС3, завершились на границе перми и триаса внедрением гранитоидных батолитов приобского комплекса. В раннем - среднем триасе регион находился в тектонически стабильных условиях, в это время происходит становление постскладчатых внутриплитных интрузий кислого и основного состава. В начале ранней юры, заложились многочисленные внутриконтинентальные бассейны и накопились конгломераты и песчаники распадской свиты геттанг-синемюрского возраста. Уже в конце триаса в регионе существовал новообразованный горный рельеф, что позволяет определять возраст начала тектонической активизации как позднетриасовый. Расположение серии впадин перед Томским надвигом КТСЗ позволяет предполагать унаследованность в распределении областей поднятия и погружения.

На протяжении ранне- и среднеюрского времени происходило разрушение позднетриасовых горных сооружений, что выразилось в закономерном уменьшении зернистости обломочного материала юрских терригенных отложений вверх по разрезу и увеличении доли тонкозернистых и угленосных осадков. Эта же закономерность характерна для раннеюрских отложений Кузнецкой и Чулымо-

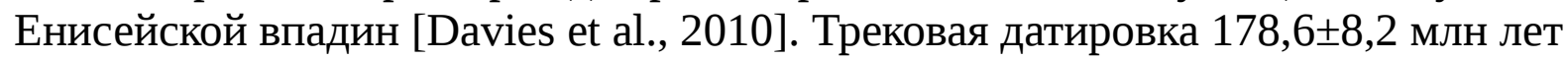
(ранняя юра, тоар), полученная по апатиту из монцодиоритов карьера Борок, 5459’15” C 8259’12” В [De Grave et al., 2007b], хорошо согласуется с геологическими данными о времени накопления обломочных пород тарбаганской серии. 
Следующий импульс тектонической активности произошел в позднеюрскораннемеловое время. Томский надвиг срезает отложения тарбаганской серии и итатской свиты, поэтому возраст его реактивации определяется не ранее чем среднеюрский. Учитывая мощность отложений осадочного выполнения Доронинской впадины, вертикальная амплитуда смещения составляла около 1,5 KM.

Юрские отложения были деформированы с образованием складчатых структур и частично размыты. На основе изучения степени метаморфизма юрских углей в Кузнецком прогибе Ю. Б. Файнер пришел к выводу, что первоначальная мощность юрских отложений в Кузнецком прогибе составляла 2,5-3,0 км [Файнер, 1967]. В настоящее время юрские отложения образуют серию разобщенных мульд в осевой части прогиба и тектонические клинья в зонах разломов, ограничивающих прогиб. Возраст позднеюрско-раннемелового орогенического этапа нуждается в уточнении. Однако, привлечение данных по более широкому региону, охватывающему всю южную часть Западной Сибири позволяет предполагать, что данный этап начался на границе юры и мела, а продолжался и завершился в раннем мелу. Осадконакопление в наиболее глубоких юрских впадинах, таких как Кузнецкая, продолжалось на протяжении средней юры, а в Чулымо-Енисейской и в верхней юре. Свидетельством размыва позднемезозойского горного сооружения являются песчаники илекской свиты, формировавшиеся в дельтовых условиях. Возраст илекской свиты в стратотипе определяется в диапазоне баррем- ранний альб [Лещинский и др., 2019]. Два этапа внутриконтинентального орогенеза (в ранней юре и в раннем мелу) также были выделены в результате изучения состава аллювиальных юрских и меловых отложений Канско-Ачинского мезозойского бассейна [Le Herron et al., 2008]. Палеомагнитные данные фиксируют значительные сдвиговые смещения в пределах Южно-Сибирского сегмента Центрально-Азиатского складчатого пояса, завершившиеся к концу мелового периода [Метелкин, 2012]. Таким образом, в мезозое КТСЗ претерпела два импульса внутриконтинентального орогенеза - триасово-юрский и юрско-меловой. Оба эти импульса приводили к реактивации позднепалеозойских надвигов КТСЗ. Движения по надвигам вызвали подъем КТСЗ, усиление денудации и привели к выведению на поверхность и размыву позднепермских и триасовых гранитоидных интрузий. Отсутствие крупнокристаллических гранитоидов приобского комплекса на территории Горловского прогиба и присутствие только порфировидных разностей близкого состава может объясняться тем, то Горловский прогиб на мезозойском этапе развивался унаследовано, как структура относительного опускания. В первой половине позднего мела, раннемеловой ороген был полностью эродирован, и на территории КТСЗ и сопредельных структур началось формирование коры выветривания. На части территории КТСЗ период выравнивания и формирования коры выветривания продолжался с позднего мела по эоцен включительно, на северо-западе образование коры выветривания прерывалось трансгрессиями Западно-Сибирского бассейна [Бабин и др, 2015].

Полученные трековые датировки апатита лежат в интервале 100-120 млн лет, что соответствует поздней части раннего мела (Таблица 2). Меловые трековые возрасты (80-140 млн лет) очень широко распространены на территории ЦАСП. 
Они характерны для Тувы [De Grave et al., 2014; Vetrov et al., 2020], Хакасии [De Grave et al., 2011], Горного Алтая [Glorie et al., 2012; Ветров и др., 2016] Восточного Саяна [Jolivet et al., 2013; Аржанникова и др., 2013] и преобладают даже в зонах активного современного горообразования, таких как Тянь-Шань [De Grave et al., 2013; Nachtergaele et al., 2018] и Джунгарский Алатау [Glorie et al., 2019]. Анализ геоморфологической позиции мест отбора образцов на трековое датирование показывает, что молодые возрасты, соответствующие неотектоническому этапу (25-5 млн лет) встречаются только в узких зонах в нижних частях тектонических уступов, в особенности ограничивающих горную страну Тянь-Шаня в целом [Sobel et al., 2006]. Большая часть трековых образцов отобранных с доорогенной поверхности выравнивания имеет меловой возраст. Очень широкое распространение меловых датировок по площади связано с тем, что они представляют «корни» последних, полностью срезанных эрозией горных систем. Большая часть более древних датировок, характеризовавшая дораннемеловую поверхность выравнивания, была эродирована вместе с горными системами раннемелового времени. Широко развитая в настоящее время доорогенная поверхность выравнивания, перекрытая позднемеловымираннепалеогеновыми корами выветривания и осадками, образовалась после срезания раннемеловых горных поднятий. Раннемеловые трековые возрасты, полученные по гранитоидам КТСЗ, свидетельствуют о проявлении позднеюрскораннемелового орогенического этапа, что согласуется с геологическими данными о реактивации Томского надвига.

Термальные истории изученных образцов показали различия в мезозойскокайнозойской истории. Для образцов Новосибирского массива и штока диоритпорфиритов в районе села Инское (обр. С-1, 14-279, 17-1346) выделяется три тектонических режима со сменой скоростей охлаждения, для образца, отобранного из Обского массива (15-519) - предполагается единый монотонный термотектонический режим со стабильной невысокой скоростью охлаждения. При сопоставлении термальных историй с геологическими данными, в особенности, с литолого-стратиграфической летописью Западно-Сибирского осадочного бассейна, выявляется следующее: а) развитие мощных кор химического выветривания в меловое время согласуется со стабильной тектонической обстановкой, установленной по Т-t-трендам образцов C-1, 14-279; б) выявленное по Т-t-тренду образца C-1 погружение в палеоцене-эоцене может быть вызвано накоплением 250-300 м толщи осадков, что, в целом, согласуется с мощностью накопления осадков палеоцен-эоценового возраста в Западно-Сибирском бассейне, и позволяет предполагать более широкие масштабы морской трансгрессии, которая по литолого-стратиграфическим данным достигла своего максимума в среднем эоцене; в) неогеновый тектонический импульс, выявленный по T-t-трендам образцов C-1, 14-279, синхронен с началом неотектонической активизации, расчленением пенеплена и формированием современного денудационного рельефа на территории КТСЗ.

Наличие неогенового этапа быстрого подъема в образцах С-1, 14-279 и 17-1346 и его отсутствие в обр. 15-519 может быть объяснено, тем, что первые три образца были отобраны ближе к приподнятой фронтальной части КТС3, а обр. 15-519 
характеризует тыловую часть зоны, вблизи погружения палеозойских пород под чехол Западно-Сибирского бассейна (рис. 1). Все термальные истории характеризуются низкой скоростью остывания породы в позднем мелу и палеогене.

Позднетриасово-раннеюрское и позднеюрско-раннемеловое орогенические события очень широко проявлены в геологических разрезах межгорных впадин [Hendrix, 2000; Новиков, 2013; De Pelsmaeker et al., 2018] и в термальной истории палеозойских пород ЦАСП [Glorie, De Grave, 2016]. Широкое развитие раннеюрских внутриконтинентальных бассейнов в полосе от южного Урала до Тихого океана [Башарина, 1975; Боголепов 1967; Бувалкин, 1978; Аржанникова и др., 2018; Желинский, 1980; Михеева и др., 2017, Guo et al., 2017, Zhang et al., 2019] указывет на значительные размеры области, охваченной близкими по возрасту тектоническими событиями. Позднетриасово-раннеюрский импульс внутриконтиентального орогенеза большинством исследователей связывается с закрытием океана Палеотетиса и столкновением с южной окраиной Евразии серии киммерийских блоков, наиболее крупным из которых является - Цайтанг (Qiangtang) [Schwab et al., 2004; Zhai et al., 2011; Roger et al., 2010]. Также в это время происходит коллизия Бадахшанского блока и образуются складчатопокровные сооружения Памира [Robinson, 2015]. В западном секторе ЦАСП раннекиммерийская орогения связывается коллизией Иранской плиты с Евразией [Zanchi et al., 2009, 2016].

Позднеюрско-раннемеловой этап внутриконтинентального орогенеза связывается с закрытием Монголо-Охотского палеоокеана и столкновением Северо-Китайского континента с Евразией [Zorin et al., 1999; Yang et al., 2015; Jolivet et al., 2017]. B западном секторе ЦАСП примерно в это же время или несколько позже, в раннем мелу, произошло причленение блока Лхаса к южной окраине Евразии [Карр et al., 2007; Zhu et al., 2013, 2016; Yang et al., 2017], что привело к тектонической перестройке в пределах Тибета [Lin et al., 2019; Yang et al., 2017], Памира [Robinson, 2015] и Тянь-Шаня [Новиков, 2013].

По аналогии с современным Альпийско-Гималайским горным поясом, в пределах которого горные сооружения сосуществуют с реликтовыми морскими бассейнами и межгорными впадинами, пространственно-временная динамика зон древнего внтуриконтинентального орогенеза также была неоднородной. Например, для угленосных бассейнов Прибайкалья орогенический импульс в пределах питающих провинций фиксируется уже в начале средней юры (174-170 млн лет), и связывается с началом закрытия Монголо-Охотского океана в самой западной его части [Михеева и др., 2017; Демонтерова и др., 2018; Аржанникова и др., 2018 ].

Своеобразие геологических проявлений этих двух орогенических этапов, обусловлено рядом факторов, из которых особенно важен климатический. Эрозия раннеюрского орогена происходила в условиях гумидного климата, а раннемеловой ороген формировался и эродировался в аридном климате [Hendrix et al., 1992; Li et al., 2014; Jolivet et al., 2015]. Можно предположить, что разрушение раннемелового орогена заняло более длительный промежуток времени, в то время 
как материал триасово-юрского орогена был быстро перемещен в синтектонические впадины в виде грубообломочных моласс.

\section{6 Выводы}

1. Позднепалеозойская КТСЗ в течении мезозоя испытала два импульса внутриконтинентального орогенеза. Первый из них произошел в позднем триасе начале юры и сопровождался заложением узких глубоких полуграбенов, выполненных грубообломочной континентальной ранне-среднеюрской молассой. Второй импульс орогенеза имеет позднеюрско-раннемеловой возраст. Он выразился в реактивации позднепалеозойского Томского надвига, по которому КТСЗ была надвинута на ранне-среднеюрские осадочные бассейны. Мезозойский орогенез привел к эрозионному вскрытию позднепермских и триасовых гранитоидных интрузий КТСЗ.

2. Наиболее вероятной причиной позднетриасово-раннеюрского орогенного события является закрытие океана Палеотетиса. Позднеюрско-раннемеловой орогенез связывается с закрытием Монголо-Охотского океана.

3. Трековые возрасты апатита из гранитоидов приобского комплекса лежат в интервале 118-100 млн лет, что соответствует аптскому и альбскому векам раннего мела. Эти датировки характеризуют поверхность выравнивания, выработанную в результате разрушения раннемелового орогена. Раннеюрская датировка несет информацию о более древнем орогеническом событии. Позднемеловой палеогеновый период тектонического покоя, доказанный геологическими данными, отражен в термических историях всех образцов.

4 Структурный план, каждой из рассмотренных реактиваций, не совпадая в деталях, наследует общие черты первичной, позднепалеозойской структуры складчатой области. В частности, происходит реактивация Томского надвига, по которому КТСЗ надвинута на Горловский передовой прогиб. Аллохтон КТСЗ проявляет себя как структура, испытывающая воздымание, а сопряженный с ней Горловский передовой прогиб испытывает относительное опускание.

\section{Благодарности.}

Исследования выполнены при финансовой поддержке РФФИ и правительства Новосибирской области, проекты 19-45-540001, 19-45-543001, и базового проекта ИГМ CO РАН. Вклад С. Начтергаеле поддержан программой PhD Fellowship FWO Flanders.

Мы благодарны А. В. Котлярову за помощь в оформлении иллюстраций и Г. С. Федосееву за замечания, позволившие улучшить текст. 


\section{Литература}

Адаменко О. М. Предалтайская впадина и проблемы формирования предгорных опусканий. Новосибирск, 1976, 184 с.

Аржанникова А.В., Жоливе М., Аржанников С.Г., Вассалло Р., Шове А. Возраст формирования и деструкции мезозойско-кайнозойской поверхности выравнивания в Восточном Саяне // Геология и геофизика, 2013, т. 54 (1), с. 894-905.

Аржанникова А.В., Фролов А.О., Аржанников С.Г., Демонтерова Е.И., Иванов А.В., Жоливе М., Рубцова М.Н., Дорожко А.Л. О корреляции юрских отложений Иркутского бассейна и юго-западного Забайкалья по данным палеоботанических и геохронологических исследований // Геология и геофизика, 2018, т. 59 (6), с. 773-791.

Ахмадщин Н. Ю., Дубинскайте О. А., Капишникова О. П., Скогорева А. С., Рубцов А. Ф., Уткин Ю. В., Черникова Т. И., Черняева Е. И., Черняев Е. В., Шамахов А. Ф., Домаренко В. А., Янкович Е. П. Лист О-45-XXXII (Тайга) геологической карты Российской Федерации, масштаба 1:200 000 (второе издание), Объяснительная записка, ВСЕГЕИ, СПб. 2008, 269 с.

Бабин Г. А., Гусев Н.И., Юрьев А. А., Уваров А. Н., Дубский В. С., Черных А. И., Щигрев А. Ф., Чусовитина Г. Д., Кораблева Т. В., Косякова Л. Н., Ляпунов И. А., Митрохин Д. В., Бычков А. И., Некипелый В. Л., Савина Ж. Н., Егоров А.С., Шор Г.М., Алексеенко В.Д., Булычев А.В., Радюкевич Н.М., Николаева Л.С., Богомолов В.П., Шипов Р.В., Суслова С.В., Сазонов В. А., Юрьева В. В., Хлебникова Т. В., Кондрашова А. К., Тереда Н. Ф. Государственная геологическая карта Российской федерации. Масштаб1:1 000000 (третье поколение). Серия Алтае-Саянская. Лист N-45 Новокузнецк. Объяснительная записка, ВСЕГЕИ, Санкт-Петербург, 2007, 665 с.

Бабин Г.А., Черных А.И., Головина А.Г., Жигалов С.В., Долгушин С.С., Ветров Е.В., Кораблева Т.В., Бодина Н.А., Светлова Н.А., Федосеев Г.С., Хилько А.П., Епифанов В.А., Лоскутов Ю.И., Лоскутов И.Ю., Михаревич М.В., Пихутин Е.А. Государственная геологическая карта Российской Федерации. Масштаб 1:1000 000 (третье поколение). Серия Алтае-Саянская. Лист N-44-Новосибирск: Объяснительная записка. Санкт-Петербург, 2015, 181 c.

Башарина Н. П., Боголепов К. В., Ермиков В. Д., Заболоцкий Е. М. Очерк тектоники мезозоя Центрально-Азиатского складчатого пояса. Новосибирск, Наука, 1974, 77 с.

Башарина Н. П. Мезозойские впадины Алтае-Саянской и Казахской складчатых областей (геологические формации и структура). Труды Института геологии и геофизики, выпуск 258, Новосибирск, Наука, 1975, 124 с.

Беляев В.И., Нечаев В.В. Государственная геологическая карта Российской Федерации масштаба 1:200 000 Издание второе. Кузбасская серия. Лист N - 45-VII (Тогучин). Объяснительная записка. Санкт-Петербург, 2015, 178 с.

Боголепов К. В. Мезозойская тектоника Сибири. М.: Наука, 1967, 328 с.

Бувалкин А.К. Юрские отложения Восточного Казахстана. Алма-Ата, «Наука» КазССР, 1978, 164 с.

Васютинская Т. Ф., Михайловский Д. В. Государственная геологическая карта СССР. Масштаб1 :1 200 000. Серия Кузбасская. Лист N-44-XII. Объяснительная записка.- Москва, 1963, 114 c. 
Вдовин В. В. Основные этапы развития рельефа // История развития рельефа Сибири и Дальнего Востока, М., «Наука», 1976, 270 с.

Вериго Е. К. Государственная геологическая карта СССР. Масштаб1 :1 200 000. Серия Кузбасская. Лист N-44-ХІ. Объяснительная записка.- Москва, 1969, 82 с.

Ветров Е.В., Буслов М.М., Де Граве Й. Эволюция тектонических событий и рельефа юго-восточной части Горного Алтая в позднем мезозое-кайнозое по данным трековой термохронологии // Геология и геофизика, 2016, т.57, №1, 125-142 с.

Волков И.А., Казьмин С.П. Палеоценовая кора выветривания как важнейший хронологический репер в геологии Западной Сибири // Вестник ВГУ. Серия: Геология. 2007, № 2, 221-223 c.

Врублевский В. А., Нагорный М. П., Рубцов А. Ф., Эрвье Ю. Ю. Геологическое строение области сопряжения Кузнецкого Алатау и Колывань-Томской складчатой зоны: Томск: 1987, 96 с.

Григорьев Н. В., Сазонов П. Т. Геология и полезные ископаемые Томь-Яйского междуречья. (Окончательный отчет Григорьевской и Подломской партий за 1960-1964 гг. лист О-45-124) Т.1. ТФ Томскгеолкома, 1964.

Демонтерова Е.И., Иванов А.В., Михеева Е.А., Аржанникова А.В., Фролов А.О., Аржанников С.Г., Брянский Н.В., Павлова Л.А., Резницкий Л.З., Зарубина О.В. Источники сноса и палеогеографические условия формирования юрских континентальных отложений на юге Сибирской платформы (по Sm-Nd и U-Pb данным) Доклады Академии наук, 2018. Т. 480, № 6, 688-692 с.

Желинский В.М. Мезозойская угленосная формация Южной Якутии. Новосибирск: Наука, 1980, 111 с.

Жимулев Ф. И., Гиллеспи Дж., Глорие С., Ветров Е. В., Борискина В. И., Караковский Е. А., Де Граве Й. Возраст питающих провинций Горловского передового прогиба: результаты датирования детритовых цирконов из песчаников балахонской серии // Геосферные исследования, 2017, № 2, 33-48 с.

Звонарев И. Н., Доронинская впадина Кузнецкого бассейна, геологический отчет, Новосибирск, 1965, 122 с.

Казаринова В. П. Коры выветривания Сибири. Формации коры выветривания ЗападноСибирской плиты и Алтае-Саянской складчатой области, М., Недра, книга 1, 1979, 221 с.

Конторович А.Э., Ершов С.В., Казаненков В.А., Карогодин Ю.Н., Конторович В.А., Лебедева Н.К., Никитенко Б.Л., Попова Н.И., Шурыгин Б.Н. Палеогеография ЗападноСибирского осадочного бассейна в меловом периоде // Геология и геофизика, 2014, Т. 55, № 5-6, 745-776 с.

Котельников А. Д., Максимов С. В., Котельников И. В., Макаренко Н. А., Субботин К. С. Объяснительная записка к листу N-44-XVIII (Черепаново) геологической карты Российской Федерации, масштаба 1:200 000 (второе издание), Издание второе. Серия Кузбасская, М.: МФ ВСЕГЕИ, 2015, 200 с.

Кулькова И. А., Волкова В. С. 1997 Ландшафты и климаты Западной Сибири в палеогене и неогене // Геология и геофизика, т.38, №3, 581-595 с. 
Кунгурцев Л.В., Федосеев Г.С., Широких В.А., Оболенский А.А., Сотников В.И., Борисенко А.С., Гимон В.О. Геодинамические комплексы и этапы развития КолываньТомской складчатой зоны (Западная Сибирь) // Геология и геофизика, 1998, Т. 39, № 1, 26-37 c.

Лещинский С. В., Файнгеру А. В., Иванцов С. В. Большой Илек - стратотип илекской свиты нижнего мела и новое местонахождение динозавровой и мамонтовой фаун юго-востока Западной Сибири // Докл. РАН, 2019, Т. 488, № 5, 513-516 с.

Малолетко А. М. Палеогеография предалтайской части Западной Сибири в мезозое и кайнозое. // Томск, Изд-во Томского ун-та, 1972. 227 с.

Матвеевская А.Л. Герцинские прогибы Обь-Зайсанской геосинклинальной системы и ее обрамления // М. Наука, 1969, 286 с.

Метелкин Д. В. Эволюция структур Центральной Азии и роль сдвиговой тектоники по палеомагнитным данным // Новосибирск, 2012, 460 с.

Михеева Е.А., Демонтерова Е.И., Фролов А.О., Аржанникова А.В., Аржанников С.Г., Черкашина Т.Ю., Иванов А.В. Смена источников снова Иркутского угольного бассейна в течение ранней и средней юры по геохимическим и Sm-Nd изотопным данным Стратиграфия // Геологическая корреляция, 2017, Т. 25, № 4, 3-25 с.

Новиков И.С. Реконструкция этапов горообразования обрамления Джунгарской впадины по литостратиграфии позднепалеозойских, мезозойских и кайнозойских отложений // Геология и Геофизика, 2013, Т. 54, № 2, 184-202 с.

Новиков И. С., Жимулев Ф. И., Ветров Е. В, Савельева П. Ю. Геологическая история и рельеф северо-западной части Алтае-Саянской области в кайнозое // Геология и геофизика, 2019, т. 60, № 7, с. 988-1003.

Обручев В.А. Основные черты кинетики и пластики неотектоники // Изв. АН СССР. Сер. геол., 1948, № 5,13-24 с.

Панов Д. И., Барабошкин Е. Е. Стратиграфическое расчленение и корреляция юрских континентальных отложений в южной части Сибирской платформы и роль эвстатического и тектонического факторов в их формировании // Вестник Московского Университета, серия 4, геология, 2015, № 3, 39 - 54 с.

Росляков Н. А., Щербаков Ю. Г., Алабин Л. В., Нестеренко Г. В., Калинин Ю. А., Рослякова Н. В., Васильев И. П., Неволько А. И., Осинцев С. Р. Минерагения области сочленения Салаира и Колывань-Томской складчатой зоны, Новосибирск, Издательство СО PAH, 2001, 243 c.

Свиридов В. Г., Краснов В. И., Сурков В. С., Калинин Ю. А., Каныгин А. В., Коробейников В. П., Мартынов В. А., Нестеренко Г. В., Осинцев С. Р., Перегоедов Л. Г., Росляков Н. А., Сердюк 3. Я., Смирнов Л. В., Хомичев В.Л. Геологическое строение и полезные ископаемые Западной Сибири, т. 1, Новосибирск, изд-во СО РАН, 1999, 228 с.

Сотников В. И., Федосеев Г.С. Кунгурцев Л.В., Борисенко А. С., Оболенский А. А., Васильев И. П., Гимон В. О. Геодинамика, магматизм и металлогения Колывань-Томской складчатой зоны, Новосибирск, Изд-во СО РАН, 1999, 227 с.

Сотников В. И., Федосеев Г.С., Пономарчук В. А., Борисенко А. С., Берзина А. Н. Гранитоидные комплексы Колывань-Томской складчатой зоны (Западная Сибирь) // Геология и геофизика 2000, №1, 120-125 с. 
Файнер Ю. Б. Государственная геологическая карта СССР, м-ба 1:200 000, лист N-45VIII, 1964.

Файнер Ю.Б. История развития Кузнецкой котловины в мезозойскую и кайнозойскую эры // Автореф. Канд. дисс., Новосибирск, 1967.

Фомичев В. Д., Алексеева Л. Э. Геологический очерк Салаира // Труды ВСЕГЕИ, новая серия, М.: Госгеолтехиздат. 1961, т. 63, 218 с.

Фомичев В. Д., Звонарев И. Н. Геология СССР том XIV Западная Сибирь (Алтайский край, Кемерово, Новосибирская, Омская, Томская области), часть 1, геологическое описание, 1967, 664 с.

Buslov, M. M., Fujiwara Y., Iwata K., and Semakov N. N. Late Paleozoic-Early Mesozoic geodynamics of Central Asia // Gondwana Research 7 (3), 2004, p. 791-808.

Davies, C., Allen, M. B., Buslov, M. M., Safonova, I. Yu. Deposition in the Kuznetsk Basin, Siberia: Insights into the Permian-Triassic transition and the Mesozoic evolution of Central Asia // Palaeogeography, Palaeoclimatology, Palaeoecology 295(1-2), 2010, p. 307-322.

Demonterova, A.V. Ivanov, E.A. Mikheeva, A.V. Arzhannikova, A.O. Frolov, S.G. Arzhannikov, N.V. Bryanskiy, L.A. Pavlova, L.Z. Reznitskii, O.V. Zarubina Source Provenance and Paleogeographic Conditions during Deposition of Jurassic Continental Sediments in the Southern Part of the Siberian Platform (Implication of Sm-Nd and U-Pb Data) // Doklady Earth Sciences, 2018, Vol. 480, Part 2, p. 720-724.

De Corte F., Bellemans F., Van den haute P., Ingelbrecht C., Nicholl C. A New U Doped Glass Certified by the European Commission for the Calibration of Fission Track Dating // Kluwer Academic Publishers, 1998, p. 67-78.

De Grave J., Van den haute P. Denudation and cooling of the Lake Teletskoye region in the Altai Mountains (South Siberia) as revealed by apatite fission-track thermochronology. Tectonophysics 349, 2002, p. 145-159.

De Grave J., De Pelsmaeker E., Zhimulev F. I., Glorie S., Buslov M. M., Van den haute P. Meso-Cenozoic building of the northern Central Asian Orogenic Belt: Thermotectonic history of the Tuva region // Tectonophysics 01, 2014, v.621, p. 44-59.

De Grave J., Buslov M.M., Van den haute P. Distant effects of India-Eurasia convergence and Mesozoic intracontinental deformation in Central Asia: Constraints from apatite fission-track thermochronology // Journal of Asian Earth Sciences 29(2-3), 2007, p. 188-204.

De Grave, J., Buslov, M.M., Van den haute, P., Dehandschutter, B., Delvaux, D. MesoCenozoic evolution of mountain range - intramontane basin systems in the Southern Siberian Altai mountains by apatite fission-track thermochronology. In: Lacombe, O., Lavé, J., Roure, F., Vergés, J. (Eds.), Thrust Belts and Foreland Basins, Frontiers in Earth Sciences. Berlin Heidelberg, 2007b, p. 457-470.

De Grave, J., Glorie, S., Buslov, M.M., Izmer, A., Fournier-Carrie, A., Batalev, V.Y., Vanhaecke, F., Elburg, M.A., Van den Haute, P. The thermo-tectonic history of the Song-Kul Plateau, Kyrgyz Tien Shan: constraints by apatite and titanite thermochronometry and zircon U/Pb dating // Gondwana Research, 20 (4), 2011a, p. 745-763.

De Grave J., Glorie, S., Zhimulev F.I., Buslov M.M., Elburg M., Van den haute P. Emplacement and exhumation of the Kuznetsk-Alatau basement (Siberia): implications for the 
tectonic evolution of the Central Asian Orogenic Belt and sediment supply to the Kuznetsk, Minusa and West Siberian Basins // Terra Nova, v.23, № 4, 2011b, p. 248 - 256.

De Grave, J., Glorie, S., Buslov, M.M., Stockli, D.F., McWilliams, M.O., Batalev, Yu, V., Van den haute, P. Thermo-tectonic history of the Issyk-kul basement (Kyrgyz northern Tien Shan, Central Asia) // Gondwana Research 23, 2013, p. 998-1020.

Delvaux D., Cloetingh S., Beekman F., Sokoutis D., Burov E., Buslov M.M., Abdrakhmatov K.E. Basin evolution in a folding lithosphere: Altai-Sayan and Tien Shan belts in Central Asia// Tectonophysics 602, 2013, p. 194-222

De Pelsmaeker E., Glorie S., Buslov M.M., Zhimulev F., Poujol M., Korobkin V.V., Vanhaecke F., Vetrov E.V., De Grave J. Late-Paleozoic emplacement and Meso-Cenozoic reactivation of the southern Kazakhstan granitoid basement // Tectonophysics 662, 2015, p. 416433.

De Pelsmaeker, E., M. Jolivet, A. Laborde, M. Poujol, C. Robin, F. I. Zhimulev, S. Nachtergaele, S. Glorie, S. De Clercq, V. Y. Batalev, and J. De Grave Source-to-sink dynamics in the Kyrgyz Tien Shan from the Jurassic to the Paleogene: Insights from sedimentological and detrital zircon U-Pb analyses // Gondwana Research 54, 2018, p. 180-204.

Dobretsov, N.L., Buslov, M.M., Delvaux, D., Berzin, N.A., Ermikov, V.D. Meso- and Cenozoic tectonics of the Central Asian mountain belt: effects of lithospheric plate interaction and mantle plume // International Geology Review 38. 1996, p. 430-466.

Fleischer R.L., Price P.B., Walker R.M. Nuclear tracks in solids: principles and applications // University of California Press, Berkeley, 1975, p. 605.

Gallagher K. Transdimensional inverse thermal history modeling for quantitative thermochronology // Journal of Geophysical Research Solid Earth, 117, 2012, p. 1-16.

Gleadow, A.J.W., Brown, R.W. Fission track thermochronology and the long-term denudational response to tectonics // Geomorphology and Global Tectonics. Summerfield, M.J. (Ed.), Wiley, New York, 2000, p. 57-75.

Glorie, S, De Grave J., Buslov M.M., Elburg M.A., Stockli D.F., Gerdes A., Van den haute P. Multi-method chronometric constraints on the evolution of the Northern Kyrgyz Tien Shan granitoids (Central Asian Orogenic Belt): from emplacement to exhumation // Journal of Asian Earth Sciences 38, 2010, p. 131-146.

Glorie S., De Grave J., Buslov M.M., Zhimulev F.I., Elburg M.A., Van den haute P. Structural control on Meso-Cenozoic tectonic reactivation and denudation in the Siberian Altai: Insights from multi-method thermochronometry // Tectonophysics, 2012, Vol. 544-545, p. 75-92.

Glorie S., De Grave J. Exhuming the Meso-Cenozoic Kyrgyz Tianshan and Siberian AltaiSayan: A review based on low-temperature thermochronology // Geoscience Frontiers 7, 2016, p. $155-170$.

Glorie S., Otasevic A., Gillespie J., Jepson G., Danisík M., Zhimulev F.I., Gurevich D., Zhang Z., Song D., Xiao W. Thermo-tectonic history of the Junggar Alatau within the Central Asian Orogenic Belt (SE Kazakhstan, NW China): Insights from integrated apatite U/Pb, fission track and (U-Th)/He thermochronology // Geoscience Frontiers 10, 2019, p. 2153-2166.

Guo Z. X., Yang Y. T., Zyabrev S., Hou Z. H. Tectonostratigraphic evolution of the MoheUpper Amur Basin reflects the final closure of the Mongol-Okhotsk Ocean in the latest Jurassic earliest Cretaceous // Journal of Asian Earth Sciences 145, 2017, p. 494-511. 
Hendrix, M.S., Graham, S.A., Carroll, A.R., Sobel, A.R., McKnight, C.L.S., B.S., Wang, Z. Sedimentary record and climatic implications of recurrent deformation in the Tian Shan: evidence from Mesozoic strata of the North Tarim, South Junggar, and Turpan basins, northwest China // Bulletin of the Geological Society of America 104, 1992, p.53-79.

Hendrix, M. S. Evolution of Mesozoic Sandstone Compositions, Southern Junggar, Northern Tarim, and Western Turpan Basins, Northwest China: A Detrital Record of the Ancestral Tian Shan // Journal of Sedimentary Research 70.3, 2000, p. 520-532.

Hendrix, M. S., T. A. Dumitru, and S. A. Graham (1994). Late Oligocene-early Miocene unroofing in the Chinese Tian Shan: An early effect of the India-Asia collision // Geology 22.6, 1994, p. 487-490.

Hurford A.J., Hammerschmidt K. ${ }^{40} \mathrm{Ar} /{ }^{39} \mathrm{Ar}$ and K/Ar dating of the Bishop and Fish Canyon Tuffs: calibration ages for fission-track dating standards // Chemical Geology 58, 1985, p. 23-32.

Jolivet, M. Mesozoic tectonic and topographic evolution of Central Asia and Tibet: a preliminary synthesis // Geological Society, London, Special Publications, 2015, 427, 19-55.

Jolivet, M., Arzhannikova, N., Frolov, A.O., Arzhannikov, S., Kulagina, N., Akulova, V., Vassallo, R. Late Jurassic - Early Cretaceous paleoenvironment evolution of the Transbaikal basins (SE Siberia): Implications for the Mongol-Okhotsk orogeny // Bulletin Société Géologique de France, 2017, 188, p. 9.

Jolivet, M., Bourquin, S., Heilbronn, G., Robin, C., Barrier, C., Dabard, M.-P., Jia, Y., De Pelsmaeker, E., Fu, B. The Upper Jurassic-Lower Cretaceous alluvial-fan deposits of the Kalaza Formation (Central Asia): tectonic pulse or increased aridity? // Geological Society, London, Special Publications, 427, 2015, doi:10.1144/SP427, p. 6.

Jolivet, M., Arzhannikov, S., Arzhannikova, A., Chauvet, A., Vassallo, R., Braucher, R. Geomorphic Mesozoic and Cenozoic evolution in the Oka-Jombolok region (East Sayan ranges, Siberia) // Journal of Asian Earth Sciences, 62, 2013, p.117-132.

Kapp, P., DeCelles, P.G., Gehrels, G.E., Heizler, M., Ding, L. Geological records of the Lhasa-Qiangtang and Indo-Asian collisions in the Nima area of central Tibet // Geological Society of America Bulletin 119, 2007, p. 917-932.

Kohn B.P., Gleadow A.J.W., Brown R.W., Gallagher K., O’Sullivan P.B., Foster D.A. Shaping the Australian crust over the last 300 million years: Insights from fission track thermotectonic and denudation studies of key terranes // Australian Journal of Earth Science, 2002, v. 49, p. 697-717.

Le Heron D. P., Buslov M. M., Davies C., Richards K., Safonova I. Evolution of Mesozoic fluvial systems along the SE flank of the West Siberian Basin, Russia // Sedimentary Geology 208, 2008, p.45-60.

Li T., Daukeev, S. Z., Kim, B. C., Tomurtogoo, O., \& Petrov, O. V. (Eds.) Atlas of geological maps of Central Asia and adjacent areas, scale 1:2 500000 // Publishing House, Beijing, 2008.

Li S., Yu X., Tan C., Steel R. Jurassic sedimentary evolution of southern Junggar Basin: Implication for palaeoclimate changes in northern Xinjiang Uygur Autonomous Region, China // Journal of Palaeogeography, 3(2), 2014, p.145-161.

Lin, X., Tian, Y., Donelick, R.A., Liu-Zeng, J., Jose Cleber, S., an Li, C., Wu, Q., Li, Z., Mesozoic and Cenozoic tectonics of the northeastern edge of the Tibetan plateau: Evidence from 
modern river detrital apatite fission-track age constraints // Journal of Asian Earth Sciences, 2019, 170, 84-95.

McDowell, F.W., McIntosh, W.C., Farley, K. A. A precise 40Ar-39Ar reference age for the Durango apatite (U-Th)/He and fission-track dating standard // Chemical Geology, 214, 2005, p. 249-263.

Molnar P, Tapponnier P. Cenozoic tectonics of Asia: effects on a continental collision // Science, 1975, 189, p. 419-426.

Nachtergaele, S., E. De Pelsmaeker, S. Glorie, F. Zhimulev, M. Jolivet, M. Danišík, M. M. Buslov, and J. De Grave "Meso-Cenozoic tectonic evolution of the Talas-Fergana region of the Kyrgyz Tien Shan revealed by low-temperature basement and detrital thermochronology” // Geoscience Frontiers 9.5, 2018, p. 1495-1514.

Robinson A. C. Mesozoic tectonics of the Gondwanan terranes of the Pamir plateau // Journal of Asian Earth Science, v. 102, 2015, p.170-179.

Roger F., Jolivet M., Malavieille J. The tectonic evolution of the Songpan-Garzê (North Tibet) and adjacent areas from Proterozoic to Present: A synthesis // Journal of Asian Earth Sciences 39, 2010, p. 254-269.

Sobel, E. R., M. Oskin, D. Burbank, and A. Mikolaichuk Exhumation of basement-cored uplifts: Example of the Kyrgyz Range quantified with apatite fission track thermochronology // Tectonics, 25 (2), 2006b, TC2008, p. 1-17.

Schwab, M., L. Ratschbacher, W. Siebel, M. McWilliams, V. Minaev, V. Lutkov, F. Chen, K. Stanek, B. Nelson, W. Frisch, and J. L. Wooden Assembly of the Pamirs: Age and origin of magmatic belts from the southern Tien Shan to the southern Pamirs and their relation to Tibet // Tectonics, 23 (4), 2004, TC4002.

Van Ranst, G., Carlos Pedrosa-Soares, A.P., Novo, T., Vermeesch, P., De Grave, J. New insights from low-temperature thermochronology into the tectonic and geomorphologic evolution of the southeast Brazilian highlands and passive margin // Geoscience Frontiers, 11 (1), 2020, p. 303324.

Vetrov E., De Grave J., Vetrova N., Zhimulev F., Nachtergaele S., Van Ranst G., Mikhailova P. Tectonic History of the South Tannuol Fault Zone (Tuva Region of the Northern Central Asian Orogenic Belt, Russia): Constraints from multi-method geochronology // Minerals 10 (1), 2020, 56; https://doi.org/10.3390/min10010056

Wagner, G.A. Fission track dating of apatites // Earth and Planetary Science Letters, 1968, v.4, p. 411-415.

Wagner G.A., Reimer G.M. Fission track tectonics: the tectonic interpretation of fission track apatite ages // Earth and Planetary Science Letters, 1972, v. 14, p. 263-268.

Wagner G., Van den Haute P. Fission track dating. - Kluwer Academic Publishers, Dordrecht, 1992, p. 285. 491-539.

Willis, B., 1928. Dead Sea problem. Rift valley or ramp valley? // Geol. Soc. Am. Bull., 39:

Yang Y. T., Guo Z. X., Song Ch., Li X., He Sh. A short-lived but significant MongolOkhotsk collisional orogeny in latest Jurassic-earliest Cretaceous // Gondwana Research, 2015, 28(10), p. 1096-1116. 
Yang Y. T., Guo Z. X., Luo Y. J. Middle-Late Jurassic tectonostratigraphic evolution of Central Asia, implications for the collision of the Karakoram-Lhasa Block with Asia // EarthScience Reviews, 166, 2017, p. 83-110.

Yin A., Harrison, T.M. Geological evolution of the Himalayan-Tibetan orogeny // Annual Review in Earth and Planetary Sciences, 2000, V.28, p.211-280.

Zanchi A., Zanchetta S., Berra F., Mattei M., Garzanti E., Molynex S., Nawab A., Sabouri J. The Eo-Cimmerian (Late? Triassic) orogeny in North Iran // Geological Society, London, Special Publications, 2009, v. 312, p. 31-55.

Zanchi A., Zanchetta S., Balini M., Ghassemi M. R. Oblique convergence during the Cimmerian collision: Evidence from the Triassic Aghdarband Basin, NE Iran //Gondwana Research, 38, 2016, p. 149-170.

Zhai, Q.-G., Jahn B.-M., Zhang R.-Y., Wang J., Su L. Triassic Subduction of the PaleoTethys in northern Tibet, China: Evidence from the geochemical and isotopic characteristics of eclogites and blueschists of the Qiangtang Block // Journal of Asian Earth Sciences, 42 (6), 2011, p. 13561370.

Zhang Q., Liang C., Liu Y., Zheng C., Li W. Provenance analysis and tectonic setting of the upper Jurassic Series in Mohe Basin, northeast China: Implication for the closure of MongolOkhotsk Ocean // Geological Journal, 2019, https://doi.org/10.1002/gj.3670

Zhimulev F. I., Gillespie J., Glorie S., Vetrov E. V., De Grave J. Tectonic history of the Kolyvan-Tomsk folded zone (KTFZ), Russia: Insight from zircon U/Pb geochronology and Nd isotopes // Geological Journal, 2020, 55 (3) p. 1913-1930

Zhu, D.C., Zhao, Z.D., Niu, Y., Dilek, Y., Hou, Z.Q., Mo, X. X. The origin and preCenozoic evolution of the Tibetan Plateau // Gondwana Research, 23, 2013, p. 1429-1454.

Zhu, D.-C., Li S.-M., Cawood P. A., Wang Q., Zhao Z.-D., Liu S.-A., Wang L.-Q. Assembly of the Lhasa and Qiangtang terranes in central Tibet by divergent double subduction Lithos, 2016, 245, p. 7-17.

Zorin, Y. A., 1999. Geodynamics of the western part of the Mongolia-Okhotsk collisional belt, Trans-Baikal region (Russia) and Mongolia // Tectonophysics, 306 (1), p. 33-56. 
Рис. 1 Геологическая схема Колывань-Томской складчатой зоны и положение юрских осадочных бассейнов (по Li, et al., 2008, Бабин и др., 2014, Ахмадщин и др., 2008)

1- Каледониды Салаира и Кузнецкого Алатау нерасчлененные; 2- среднедевонскораннекарбоновые отложения, деформированный чехол эпикаледонских впадин; 3среднедевонские вулканогенные и вулканомиктовые отложения Колывань-Томской складчатой зоны (КТСЗ), буготакская, тогучинская и митрофановская свиты; 4верхнедевонские терригенные отложения КТС3, пачинская и юргинская свиты; 5нижнекарбоновые отложения КТСЗ, инская серия; 6- карбон-нижнепермские отложения Горловского, Зарубинского и Кузнецкого прогибов; 7- средне-верхнепермские отложения Горловского, Зарубинского и Кузнецкого прогибов; 8- ранне-среднеюрские отложения наложенных впадин; 9- юрские отложения, тектонически перекрытые палеозойскими породами КТС3, 10- меловые отложения; 11- лейкограниты ранне-среднетриасового барлакского комплекса; 12 - граниты позднепермского приобского комплекса КТСЗ и палеозойские гранитоиды Салаира нерасчлененные; 13-кайнозойские отложения чехла Западно-Сибирской плиты; 11 (а) главные разломы и надвиги, (б) - Томский надвиг (фронтальный надвиг КТС3); 15- местоположение фотографий, представленных на рис. 4а и 4б; 16- номерами обозначены юрские впадины: 1-Улановская, Доронинская, 3Карагужевская, 4- Бобровская. Звездочками обозначены образцы гранитоидов, отобранные на трековое датирование апатита.

На врезке показано положение рисунка 1 в структуре Центрально-Азиатского складчатого пояса (ЦАСП).

Рис. 2 Литологические колонки юрских отложений Улановской и Доронинской впадин (по Беляев, Нечаев, 2015, Ахмадщин и др., 2008).

1-глины (меловые отложения), 2- линзы бокситов, 3- песчаники, 4- алевролиты, 5аргиллиты, 6-конгломераты, 7- угольные пласты, 8- спорово-пыльцевые комплексы, 9фрагменты макрофлоры. Стратиграфические подразделения: $\mathrm{J}_{1} m k$ - макаровская свита, $\mathrm{J}_{1} i l-$ иланская свита, $\mathrm{J}_{1} i t-$ итатская свита, $\mathrm{K}_{1-2} k s$ - кийская свита, $\mathrm{K}_{2} s m n$ - симоновская свита, $\mathrm{J}_{1} r s-$ распадская свита, $\mathrm{J}_{1} a b$ - абашевская свита, $\mathrm{J}_{1}$ os-осиновская свита, $\mathrm{J}_{1-2}$ tr-терсюкская свита.

Рис. 3 Геологическая схема и разрез Доронинской впадины по (Беляев, Нечаев, 2015, Звонарев, 1965, Файнер, 1964).

1-4- юрские отложения Доронинской впадины: 1-терсюкская свита, 2-осиновская свита, 3абашевская свита, 4- распадская свита, 5- пермские отложения, 6- карбоновые отложения 7-девонские отложения, 8- кембрийские отложения, 9- плагиогранит-порфиры кембрийского возраста, 10- габбро-диабазы кембрийского возраста, 11-плагиограниты новолушниковского комплекса, раннеордовикского возраста, 12- гранодиориты и граниты улантовского комплекса, силурийского возраста, 13а- разрывные нарушения, 13б- Томский (Томско-Каменский) надвиг, 14- стратиграфические и интрузивные контакты, 15элементы залегания слоистости.

Рис. 4 Фотографии обнажений юрских пород и мел-палеогеновой коры выветривания. 
4а. Конгломераты галечные в нижней части распадской свиты на южном борту Доронинской впадины. (5452'38.80"С 84³1'10.65"В).

В карьере вскрыта толща слабосцементированных желтовато-серых грубозернистых песчаников и галечных конгломератов с включениями валунов. В составе обломков преобладают песчаники вулканомиктовые, разнозернистые граувакковые и плагиоклазовые порфириты, также встречаются гранодиориты, известняки, кремни, микрокварциты. Состав обломков хорошо соответствует набору горных пород северной части Салаирского кряжа.

46 геологический разрез в борту Колыванского каменного карьера (55²1'19.73"С, 8246'4.82"В). Пояснения в тексте.

Рис. 5 Фото зерен апатита пробы 14-279 в сканирующем микроскопе Nikon при увеличении 625-кратном (слева) и 125-кратном (справа) увеличении.

Рис. 6 Термальные истории и гистограммы распределения трековых длин в апатитах из гранитоидов КТСЗ. На термальных история: по вертикали - температура в градусах Цельсия, по горизонтали - возраст в млн лет, цветная шкала отражает вероятность построенной модели. На гистограммах: по вертикали - частота встречаемости треков, по горизонтали - длина треков в мкм, $\mathrm{L}_{\mathrm{m}}$ - средняя трековая длина со стандартным отклонением (б), $\mathrm{n}_{1}$ - количество измерений естественных горизонтальных ограниченных треков. 
Таблица 1 Места отбора проб на трековый анализ апатита

\begin{tabular}{|c|c|c|c|c|c|c|c|c|}
\hline & Проба & Долгота & Широта & Абс. высота, м & Порода & Привязка & Массив & Комплекс \\
\hline 1 & $\mathrm{C}-1$ & $82^{\circ} 53^{\prime} 47.46^{\prime \prime B}$ & $54^{\circ} 58^{\prime} 13.85^{\prime \prime C}$ & 118 & монцогранит & Карьер Иподромский,г. Новосибирск & Новосибирский & приобский \\
\hline 2 & $14-279$ & $82^{\circ} 55^{\prime} 16.68 " \mathrm{~B}$ & $54^{\circ} 59^{\prime} 27.36^{\prime \prime C} \mathrm{C}$ & 102 & граносиенит & Кривощековский карьер, г. Новосибирск & Новосибирский & приобский \\
\hline 3 & $15-519$ & $83^{\circ} 44^{\prime} 32.30^{\prime \prime B}$ & $55^{\circ} 41 ' 19.26 " \mathrm{C}$ & 110 & монцогранит & Село Новобибеево, коренные выходы & Обской & приобский \\
\hline 4 & $17-1346$ & $83^{\circ} 12^{\prime} 15.31 " \mathrm{~B}$ & $54^{\circ} 12^{\prime} 33.51^{\prime \prime C}$ & 240 & $\begin{array}{c}\text { гранодиорит- } \\
\text { порфириты }\end{array}$ & Карьер, поселок Инской & & приобский (?) \\
\hline
\end{tabular}


Таблица 2 Результаты трекового анализа апатита

$\mathrm{n}$

\begin{tabular}{|c|c|c|c|c|c|c|c|c|c|c|c|c|c|c|}
\hline & Проба & $n$ & $\rho_{s}( \pm 1 \sigma)$ & $\mathrm{N}_{\mathrm{s}}$ & $\rho_{i}( \pm 1 \sigma)$ & $\mathrm{N}_{\mathrm{i}}$ & $\rho_{d}( \pm 1 \sigma)$ & $\mathrm{N}_{\mathrm{d}}$ & $\rho_{\mathrm{s}} / \rho_{\mathrm{i}}$ & $\mathrm{P}\left(\mathrm{x}^{2}\right)$ & $\mathrm{t}(\zeta)$ & $l_{\mathrm{m}}$ & $\mathrm{n}_{1}$ & $\sigma$ \\
\hline 1 & $\mathrm{C}-1$ & 10 & $6,514(0,138)$ & 2220 & $4,589(0,116)$ & 1564 & $5,307(0,118)$ & 2033 & $1,42 \pm 0,05$ & 0,97 & $118,1 \pm 12,9$ & 10,4 & 69 & 2,1 \\
\hline 2 & $14-279$ & 10 & $8,882(0,195)$ & 3757 & $7,223(0,176)$ & 2072 & $5,305(0,118)$ & 2034 & $1,23 \pm 0,04$ & 0,74 & $99,9 \pm 12,6$ & 11,9 & 70 & 1,6 \\
\hline 3 & $15-519$ & 30 & $5,011(0,086)$ & 3403 & $3,985(0,077)$ & 2706 & $5,306(0,118)$ & 2034 & $1,26 \pm 0,03$ & 0,69 & $108,9 \pm 11,6$ & 13,2 & 50 & 1,5 \\
\hline 4 & $17-1346$ & 47 & $4,249(0,100)$ & 1805 & $2,559(0,077)$ & 1087 & $4,667(0,074)$ & 3932 & $1,70 \pm 0,07$ & 0,72 & $110,9 \pm 5$ & 12,9 & 51 & 1 \\
\hline
\end{tabular}

количество проанализированных зерен

$\rho_{s}, \rho_{i}, \rho_{d}$ - плотности спонтанных $\left(\rho_{s}\right)$, индуцированных $\left(\rho_{i}\right)$ треков и индуцированных треков на внешнем детекторе $\left(\rho_{d}\right)$ представленные в $10^{5}$ треков/см ${ }^{2}$

$N_{s}, N_{i}, N_{d}$ - количество спонтанных $\left(N_{s}\right)$, индуцированных $\left(N_{s}\right)$ треков и индуцированных треков на внешнем детекторе $\left(N_{d}\right)$

$\mathrm{P}\left(\mathrm{X}^{2}\right)$ - вероятность постоянного соотношения $\rho_{s} / \rho_{i}$ в датируемых зернах

$\mathrm{t}(\zeta)$ - трековые возрасты апатита (млн лет)

$l_{m}, n_{1}, \sigma$ - данные трековых длин апатита: средняя трековая длина в микрометрах $\left(l_{m}\right)$ со стандартным отклонением (б), полученные из измерений количества $\left(\mathrm{n}_{1}\right)$ естественных горизонтальных ограниченных треков. 


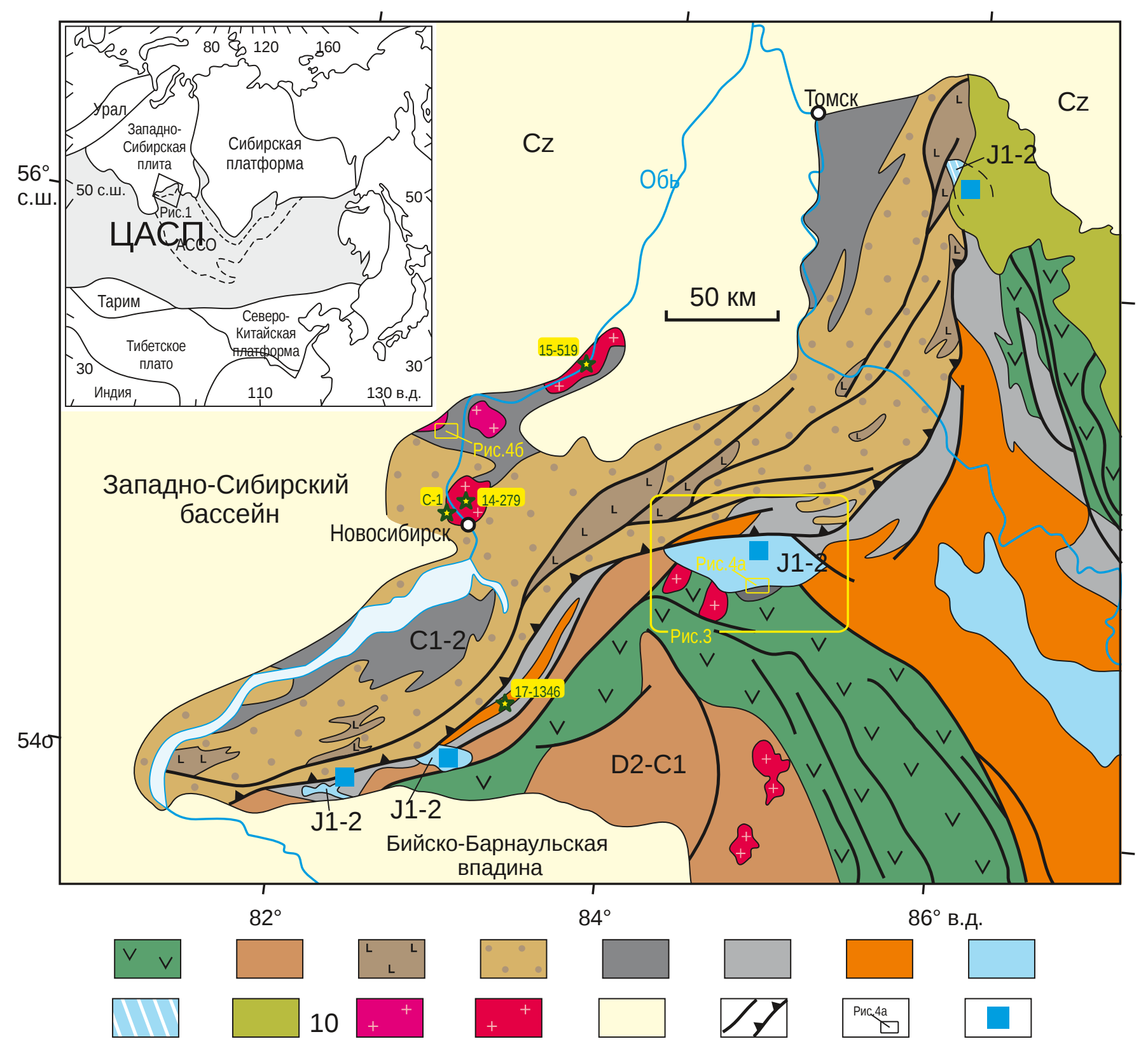




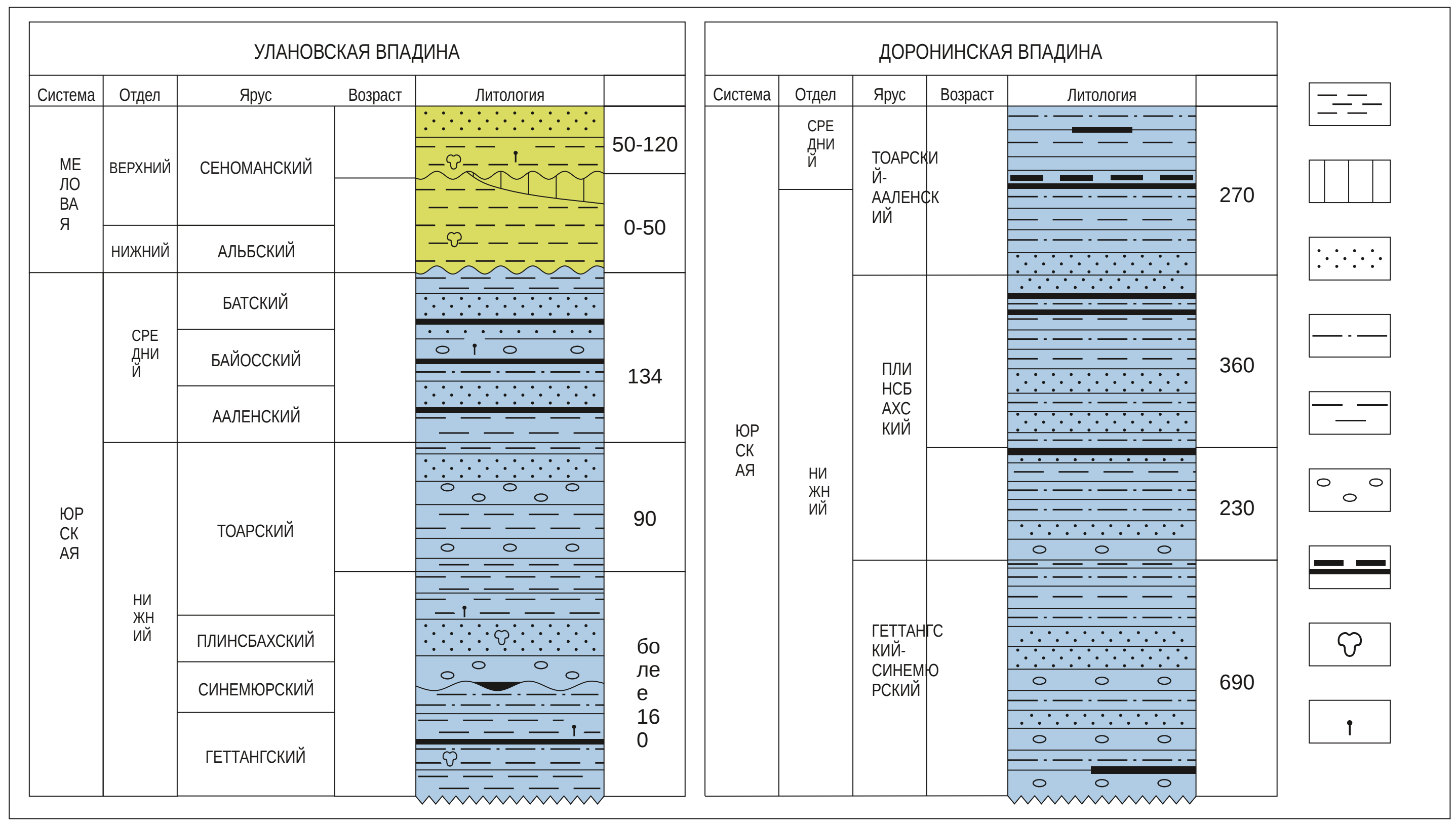




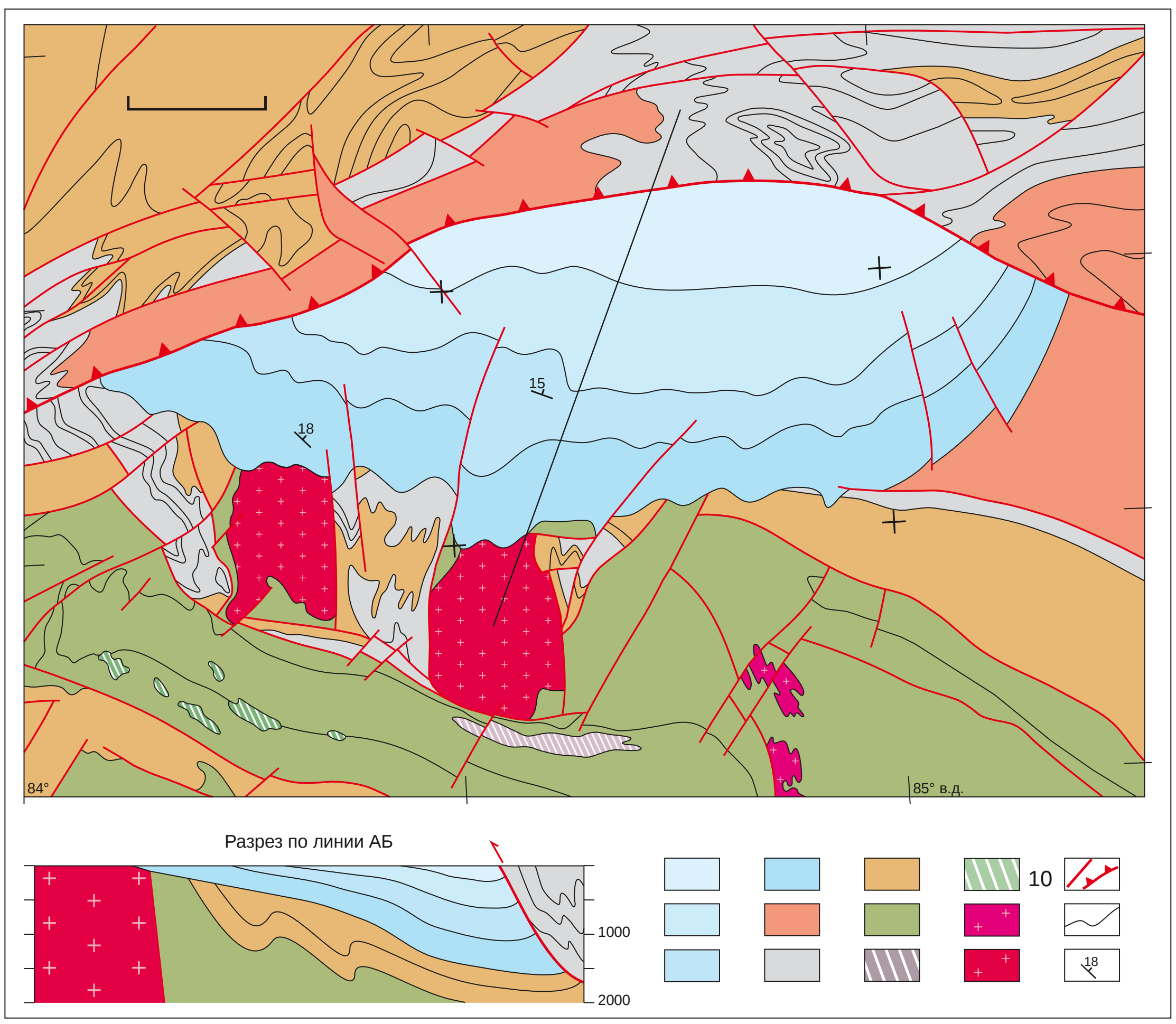



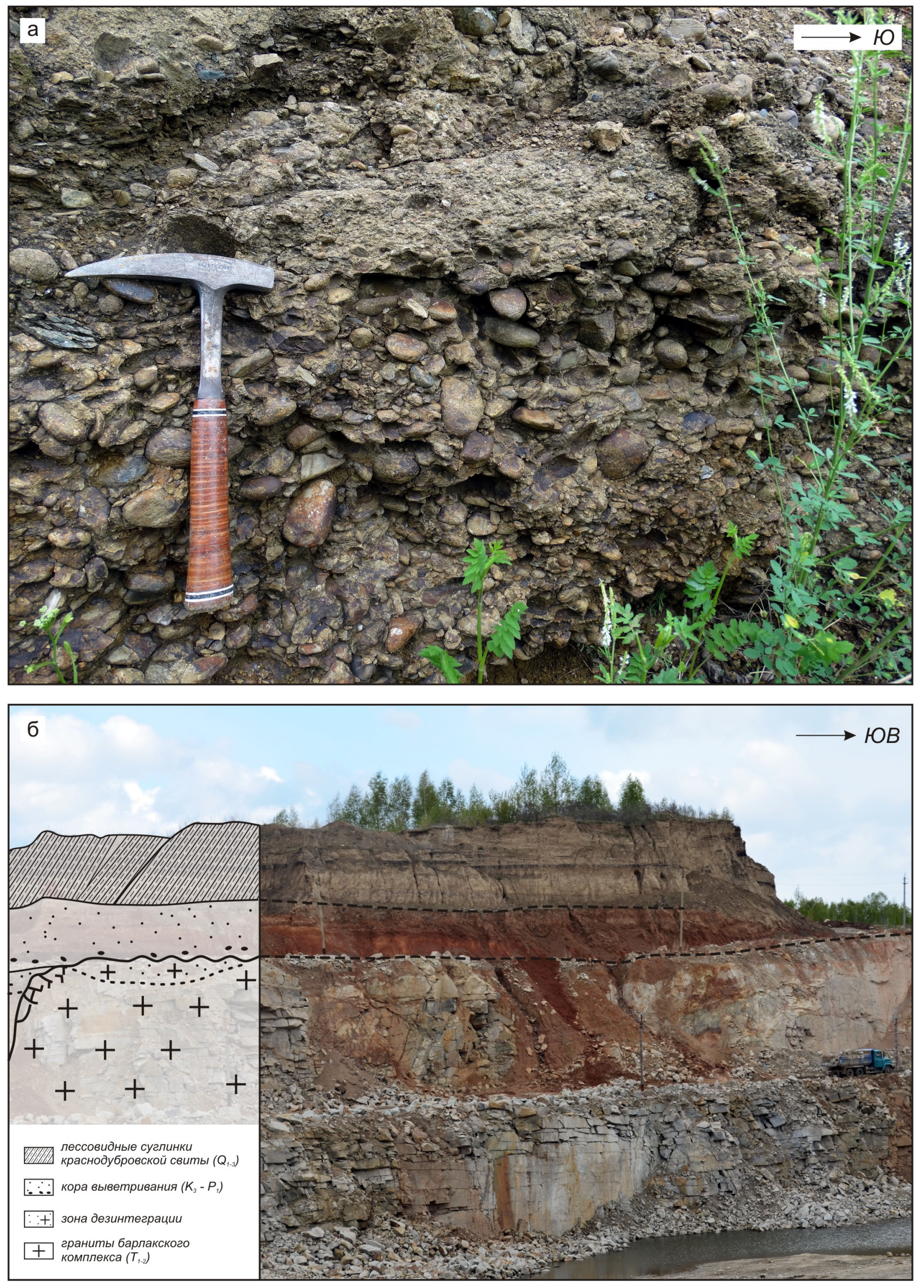

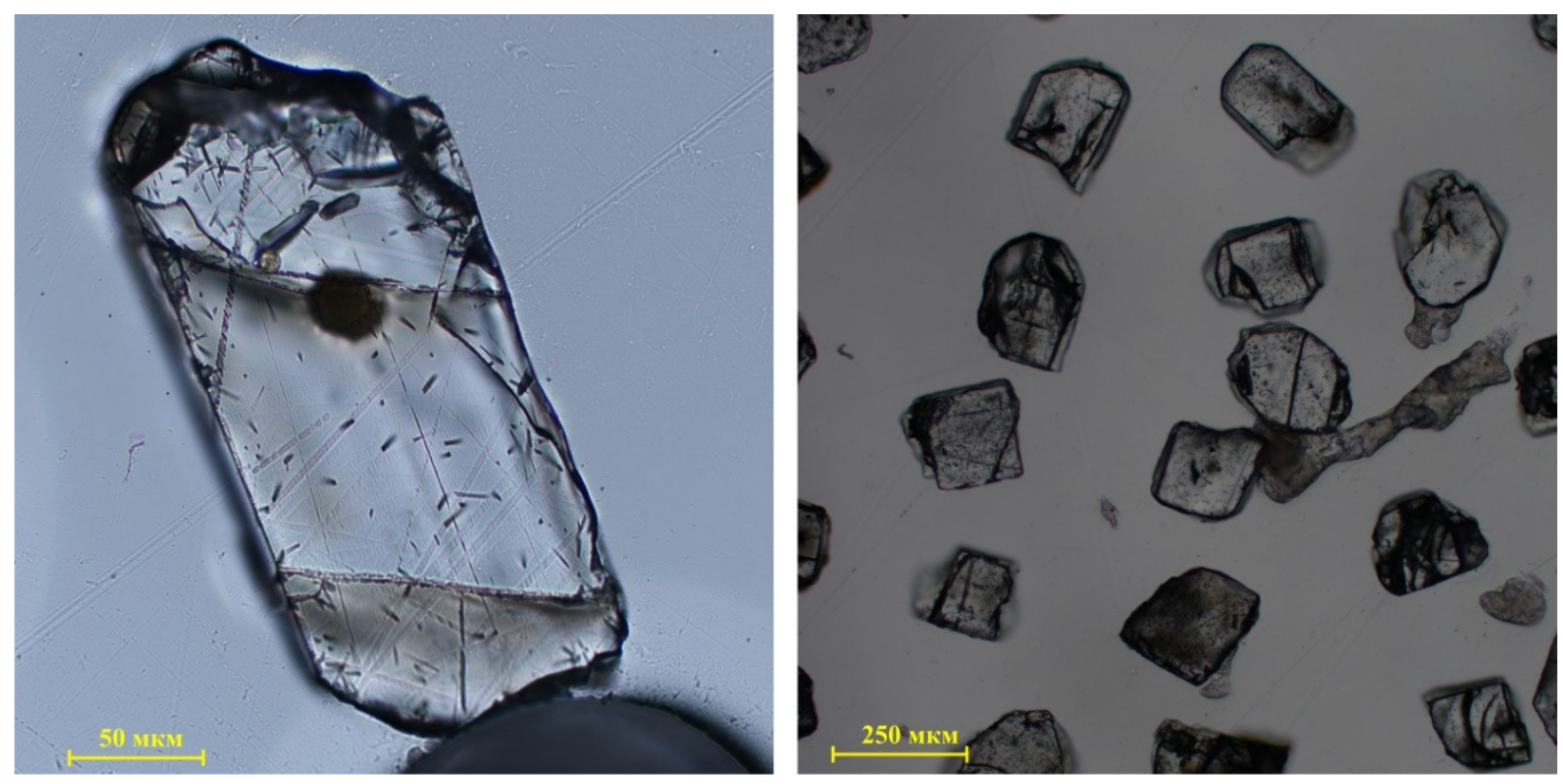

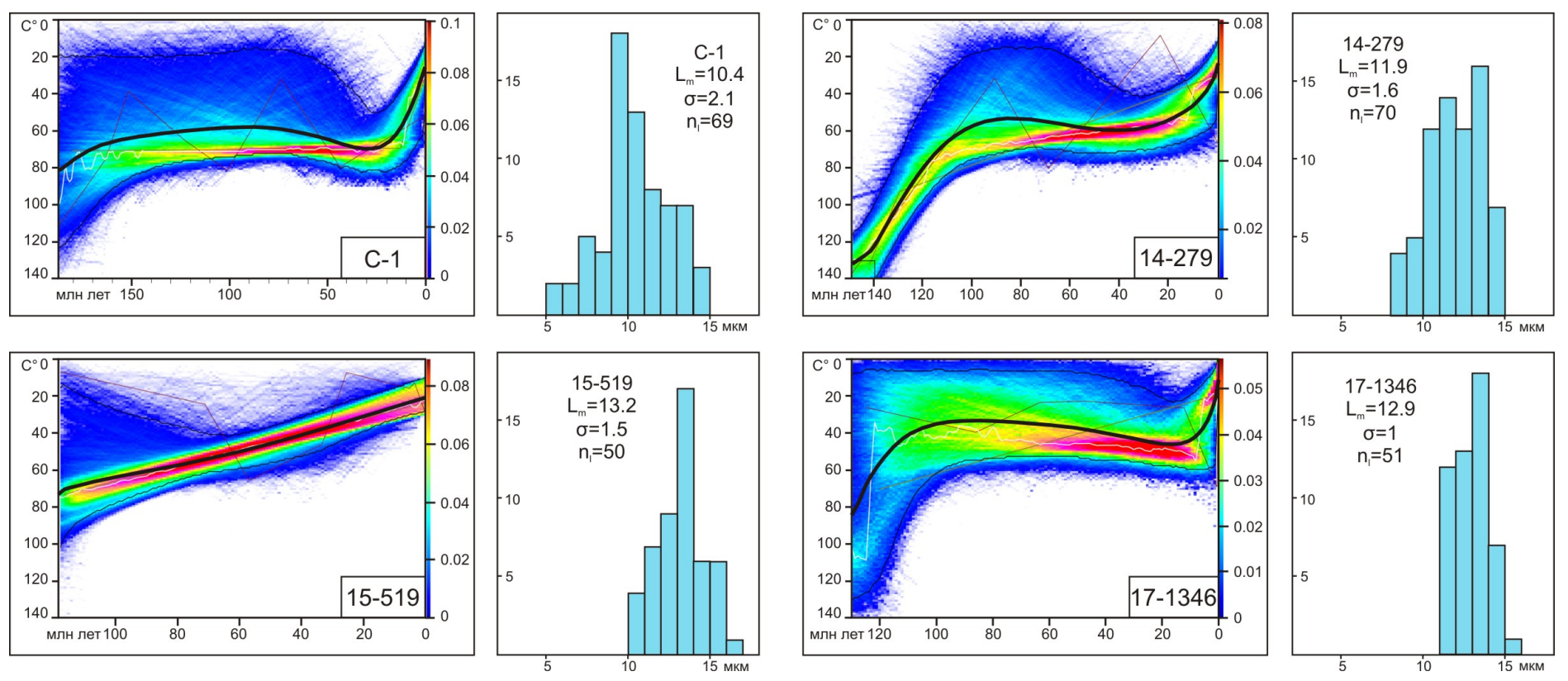